\title{
Botswana: 2007 Article IV Consultation-Staff Report; Public Information Notice on the Executive Board Discussion; and Statement by the Executive Director for Botswana
}

Under Article IV of the IMF's Articles of Agreement, the IMF holds bilateral discussions with members, usually every year. In the context of the 2007 Article IV consultation with Botswana, the following documents have been released and are included in this package:

- $\quad$ The staff report for the 2007 Article IV consultation, prepared by a staff team of the IMF, following discussions that ended on September 27, 2007, with the officials of Botswana on economic developments and policies. Based on information available at the time of these discussions, the staff report was completed on November 9, 2007. The views expressed in the staff report are those of the staff team and do not necessarily reflect the views of the Executive Board of the IMF.

- $\quad$ A Public Information Notice (PIN) summarizing the views of the Executive Board as expressed during its December 7, 2007 discussion of the staff report that concluded the Article IV consultation.

- $\quad$ A statement by the Executive Director for Botswana.

The documents listed below have been or will be separately released.

Financial Sector Stability Assessment

Selected Issues Paper

The policy of publication of staff reports and other documents allows for the deletion of market-sensitive information.

To assist the IMF in evaluating the publication policy, reader comments are invited and may be sent by e-mail to publicationpolicy@imf.org.

Copies of this report are available to the public from

International Monetary Fund • Publication Services

$70019^{\text {th }}$ Street, N.W. • Washington, D.C. 20431

Telephone: (202) 623-7430 • Telefax: (202) 623-7201

E-mail: publications@imf.org•Internet: http://www.imf.org

Price: $\$ 18.00$ a copy

International Monetary Fund

Washington, D.C. 

INTERNATIONAL MONETARY FUND

BOTSWANA

Staff Report for the 2007 Article IV Consultation

Prepared by Staff Representatives for the 2007 Consultation with Botswana

Approved by David Andrews and Anthony Boote

November 9, 2007

Dates: September 17-September 27, 2007.

Team: Mses. Stotsky (head) and Deléchat, and Messrs. Clausen, Gaertner, and Sitima-wina (all AFR).

Relations with the Fund: The last Article IV consultation was concluded in December 2006.

Exchange rate regime: Botswana has accepted the obligations of Article VIII. 
I. Overview ……

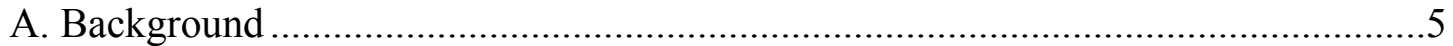

B. The Medium Term and Risks to the Outlook..........................................................6

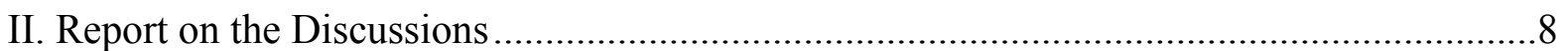

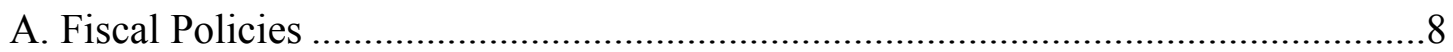

B. Monetary and Exchange Rate Policies to Control Inflation, Maintain Competitiveness, and Respond Flexibly to Shocks .........................................12

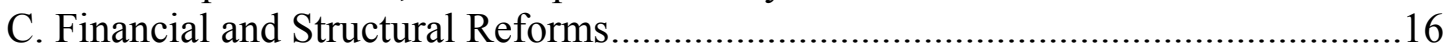

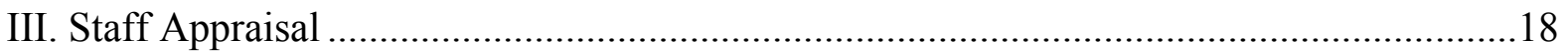

Text Tables

1. Medium-Term Economic and Financial Indicators.........................................................

2. Medium-Term Fiscal Outlook and Sustainability Benchmarks .........................................11

Figures

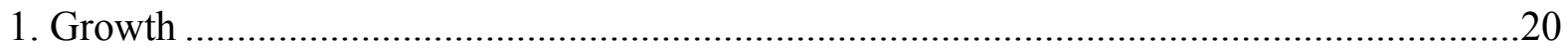

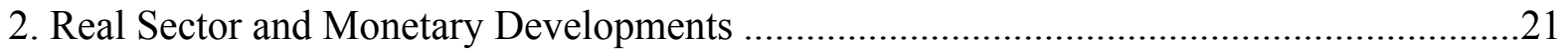

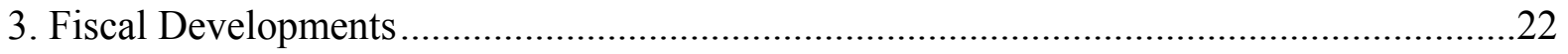

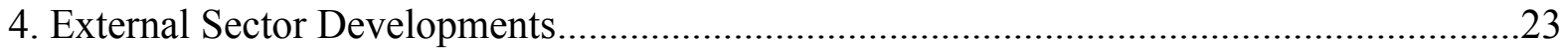

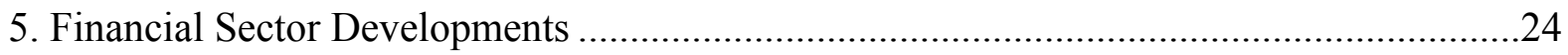

Boxes

1. Calculating Fiscal Sustainability Benchmarks for Botswana ...........................................10

2. Exchange Rate Assessment......................................................................................

3. Reform of the Nonbank Financial Institutions-Financial Sector Assessment Program

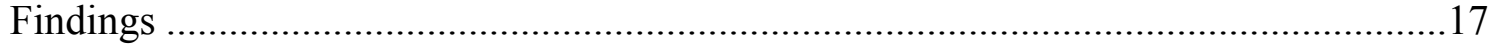

Tables

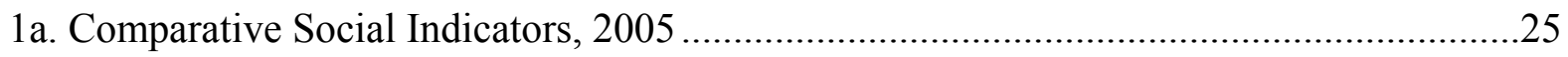

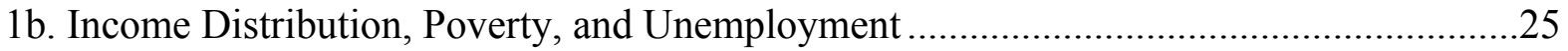

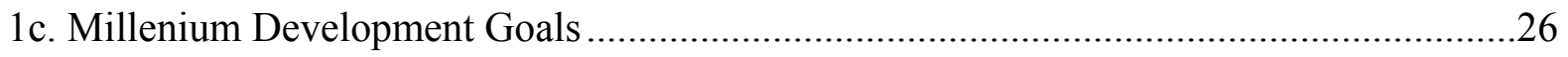

2. Selected Economic and Financial Indicators, 2003-2007.............................................2

3. Sectoral GDP and Savings-Investment Balances, 2002/03-2010/11 …..........................28

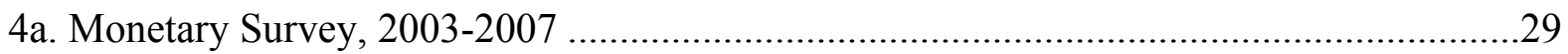

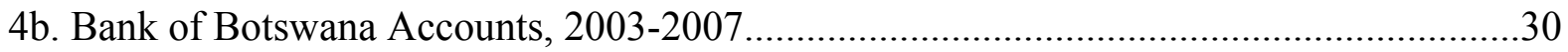

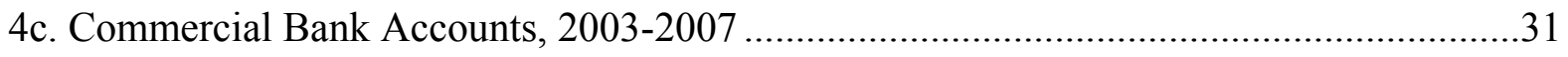

5a. Central Government Operations, 2003/04-2007/08 .........................................................32

5b. Central Government Operations, 2003/04-2007/08 ..........................................................3

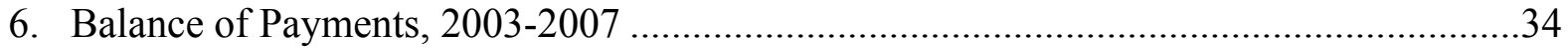




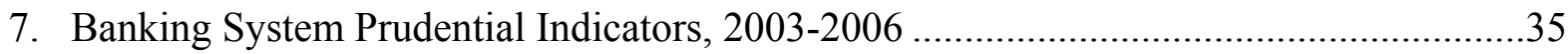

8. Medium-Term Economic and Financial Indicators, 2007-2011 ....................................36

9a. Central Government Operations, 2007/08-2010/11 _..........................................................37

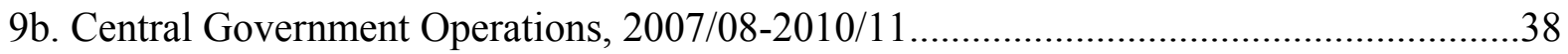

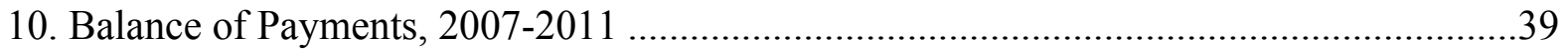

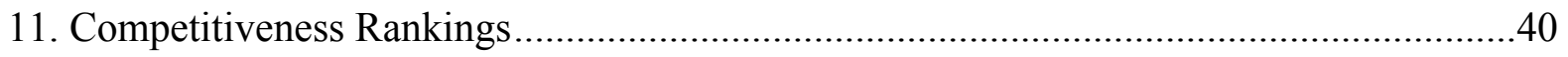

Appendices

External Debt Sustainability Analysis .................................................................................4 


\section{EXECUTIVE SUMMARY}

- Recent economic developments in Botswana have been positive. Growth has picked up, especially in the non-mineral economy. Inflation has fallen substantially, stabilizing near the top of the Bank of Botswana (BoB) target range, though inflation risks remain. Continued high mineral prices are contributing to healthy fiscal and balance of payments surpluses. Though the incidence of poverty, unemployment, and HIV/AIDS remain high, all have declined recently.

- The economy is slowly diversifying but the expected sharp decline in diamond production after 2020 poses a challenge. Continued and prospective development of minerals and large-scale investment in electricity generation are projected to support fiscal and balance of payments surpluses through 2011, but more rapid diversification away from diamonds is needed to support growth and generate employment.

- Maintaining fiscal surpluses over the medium term is essential to sustain budgetary spending when diamond revenues decline. Although the authorities have met their fiscal goal of keeping public expenditures below 40 percent of GDP, the next National Development Plan (NDP 10) should have more ambitious goals for maintaining fiscal savings and boosting non-mineral revenues.

- The creation of an explicit sovereign wealth fund could strengthen support for fiscal savings by underscoring the link between fiscal surpluses now and more stable spending in the future when diamond revenues decline, and also the need to channel the bulk of returns on public financial assets back to government.

- Striking an appropriate balance between monetary and exchange rate policy objectives is critical. Devaluation provided a competitive boost to exports, but the rapid expansion in $\mathrm{BoB}$ certificates (BoBCs) to absorb excess liquidity is imposing a high interest cost on the bank. Further reduction in the rate of crawl, consistent with inflation differentials, would facilitate further interest rate reductions. The real effective exchange rate has stabilized in the past year at close to its equilibrium value.

- The banking sector is sound and near-term risks are well contained, but the agenda for financial sector reform is still sizable. The authorities should build on the Financial Sector Assessment Program (FSAP) to formulate a reform plan that would substantially strengthen supervision of nonbank financial institutions (NBFIs).

- Structural reforms are needed to raise productivity. The privatization agenda has slowed, but large parastatals should still be privatized, with appropriate regulation. The skills mismatch should be addressed by reforming education and vocational training. Recent government initiatives on foreign investment and competition policy need to be completed. Liberalizing administered prices would improve efficiency. Better statistics would enhance policy analysis. 


\section{OVERVIEW}

1. Sound macroeconomic policies, good governance, and high levels of investment, supported by diamond and other mineral production, have moved Botswana well into the ranks of middle-income countries (Figure 1). Real GDP growth has averaged $4 \frac{1}{2}$ percent for the past four years, a solid performance, but below the expectations of the National Development Plan 9 (NDP 9), which ends with fiscal year 2008/09. Inflation has fallen near the average for the South African rand area and balance of payments and fiscal surpluses have built reserves and reduced Botswana's already low external debt.

2. Despite impressive progress in raising living standards, more needs to be done. Although the incidence of HIV/AIDS has begun to fall, it continues to exact a heavy toll; and unemployment and poverty rates, though declining, remain high (Tables $1 \mathrm{a}$ and $1 \mathrm{~b}$ ). Botswana still has a way to go to meet all the Millennium Development Goals (MDGs) (Table 1c).

\section{A. Background}

3. Recent developments have been favorable.

- After a temporary slowdown, growth in 2006/07 recovered to an estimated $53 / 4$ percent on increases in both mineral and non-mineral activities, including tourism and manufacturing (Tables 2 and 3 and Figure 2).

- Inflation has fallen substantially since peaking in April 2006, but it is still near the top of the $\mathrm{BoB}$ target range. The $\mathrm{BoB}$ policy interest rate was lowered half a percent to $14 \frac{1}{2}$ percent in June. Real interest rates were rising as inflation declined. A large increase in administered fuel prices in July pushed inflation up but it is still within the BoB objective of 4-7 percent. M3 has grown steadily and private sector credit rose 19 percent in July 2007 year-on-year (Tables 4a, 4b, and 4c).

- Another large fiscal surplus is expected in 2007/08. High revenues from minerals and the South African Customs Union (SACU) and slow capital spending contributed to a fiscal surplus of 12 percent of GDP in 2006/07 (Tables 5a and 5b and Figure 3). Staff project a surplus of 8 percent of GDP in 2007/08, based on robust non-mineral revenues and lower-than-budgeted spending, compared to a budgeted surplus of 2 percent of GDP.

- Exchange rates have stabilized in the past year. The pula depreciated significantly in nominal and real effective terms after devaluations in 2004 and 2005 and the shift in 2005 to a crawling peg (Figure 4). ${ }^{1}$ Fiscal restraint, capital account outflows, and tight

\footnotetext{
${ }^{1}$ The rate of crawl of the pula is set at the difference between the inflation objective and the forecast inflation of trading partners. The authorities do not disclose the parameters of the crawl.
} 
monetary policy have helped to contain inflationary pressures so that the real effective exchange rate (REER) is now about 10 percent below its pre-2004 peak. The decision in July 2007 to slow the rate of the crawl because of narrowing inflation differentials between Botswana and trading partners will also help contain inflation.

- Continued high mineral prices and a decline in imports contributed to a current account surplus of almost 19 $1 / 2$ percent of GDP in 2006 (Table 6). Copper and nickel exports surged on a major uptick in prices. International reserves-which include the Pula Fund of longer-term assets-increased to 25 months of prospective imports of goods and services by the end of $2006{ }^{2}$

- The financial sector is healthy but shallow; high systemic excess liquidity is a continuing problem. Financial sector prudential indicators are solid and the profitability of the commercial banking system is among the world's highest (Table 7 and Figure 5). However, indicators of financial sector depth are well below those of comparable countries. The stock of BoBCs, the main instrument for absorbing liquidity, has expanded rapidly in recent years, to about one-quarter of GDP; commercial banks now hold over half their assets in BoBCs. The rising interest costs of BoBCs, though offset by other sources of $\mathrm{BoB}$ income, reached 3 percent of GDP in 2006.

\section{B. The Medium Term and Risks to the Outlook}

4. The economy is diversifying slowly but will need to meet the challenges of the expected sharp decline in diamond production some time after 2020. ${ }^{3}$ Continued and prospective development of other minerals, including copper, nickel, and coal; large-scale investment in electricity generation; and some promising non-mineral projects should support growth, and maintain fiscal and balance of payments surpluses through 2011 (Tables 8, 9a, 9b, and 10 and Text Table on Medium-Term Economic and Financial Indicators). Nonetheless, the relatively short horizon to where diamond production is expected to fall off means that non-diamond growth must accelerate significantly before then to avoid a contraction of the economy. Even in a growing economy, it will be difficult to replace the government's high share of diamond export revenues.

\footnotetext{
${ }^{2}$ The Pula Fund, in which the government has accumulated a two-thirds share through fiscal surpluses, is managed by the BoB.

${ }^{3}$ These estimates may be substantially influenced by technological change or new discoveries.
} 
Medium-Term Economic and Financial Indicators, 2007-2011

\begin{tabular}{|c|c|c|c|c|c|}
\hline & 2007 & 2008 & 2009 & 2010 & 2011 \\
\hline & \multicolumn{5}{|c|}{ (Annual percentage change) } \\
\hline Real GDP ${ }^{1}$ & 4.3 & 6.0 & 3.8 & 5.5 & 6.9 \\
\hline Mineral & -4.3 & 1.9 & -2.7 & 2.0 & 4.0 \\
\hline Non-mineral $^{2}$ & 10.4 & 8.6 & 7.6 & 7.3 & 8.3 \\
\hline Consumer prices (average) & 7.0 & 7.0 & 6.1 & 5.6 & 5.0 \\
\hline \multirow[t]{2}{*}{ Consumer prices (end of period) } & 7.4 & 6.5 & 5.8 & 5.3 & 5.0 \\
\hline & \multicolumn{5}{|c|}{ (Percent of GDP) } \\
\hline Overall fiscal balance (deficit -$)^{3}$ & 8.0 & 6.4 & 5.0 & 3.5 & 2.3 \\
\hline Non-mineral primary balance ${ }^{4}$ & -17.6 & -17.2 & -17.0 & -16.6 & -16.7 \\
\hline Current account balance & 20.4 & 9.6 & 8.8 & 5.6 & 5.5 \\
\hline \multirow[t]{2}{*}{ Balance of payments } & 17.2 & 12.1 & 11.2 & 7.5 & 7.1 \\
\hline & \multicolumn{5}{|c|}{ (US\$ millions) } \\
\hline Change in reserves (increase -) & $-1,953$ & $-1,507$ & $-1,484$ & $-1,071$ & $-1,093$ \\
\hline Gross official reserves (end of period) & 9,907 & 11,414 & 12,898 & 13,968 & 15,061 \\
\hline In months of imports of goods and services ${ }^{5}$ & 24.4 & 26.9 & 28.6 & 29.4 & 29.5 \\
\hline
\end{tabular}

Sources: Botswana authorities; and IMF staff estimates and projections.

${ }^{1}$ Year beginning July 1. Based on data included in the February 2007 National Accounts Stats Brief from the Central Statistics Office, to reflect pending revision of the July 2007 National Accounts Stats Brief.

${ }^{2}$ Stronger growth in non-mineral real GDP over the medium-term largely reflects significant investment in electricity generation, including the Morupule Power Station and the Mmamabula Energy Project.

${ }^{3}$ Year beginning April 1.

${ }^{4}$ The non-mineral primary balance is computed as the difference between non-mineral revenue and expenditure (excluding interest receipts and interest payments), divided by non-mineral GDP.

${ }^{5}$ Based on imports of goods and services for the following year. 
5. Despite the positive medium-term view, there are a number of risks:

- The continued dependence on mineral exports and revenues makes the economy susceptible to a significant decline in the price of diamonds, copper, or nickel. If growth declines in industrialized and emerging market economies, diamond prices or sales could drop, with negative effects on Botswana's fiscal and current account balances. In addition, non-mineral growth is needed to generate employment.

- The financial system faces challenges. The sizable pension and insurance sectors are only lightly supervised, the NBFI regulatory authority is just gearing up, and the rapid growth in consumer lending in recent years presents untested risks. The interest burden from the growing stock of BoBCs is high.

- There are near-terms risks of inflation. Regional drought, which may further push up food prices; power shortages, which may increase electricity prices; and additional administrative price adjustments (with one-off effects) may make it difficult for the BoB to reach its 3-6 percent medium-term inflation objective.

\section{REPORT ON THE DISCUSSIONS}

6. Policy discussions focused on three challenges to sustainable growth: (i) fiscal policies to support longer-term sustainability; (ii) monetary and exchange rate policies to control inflation, maintain competitiveness, and respond flexibly to shocks; and (iii) financial and structural reforms to support growth and stability.

\section{A. Fiscal Policies}

7. To contain inflationary pressures and move toward a sustainable medium-term position, the staff recommended that the authorities aim for a surplus of at least 9-10 percent of GDP this fiscal year (2007/08) through continued efforts to boost recurrent revenues and restrain expenditures. ${ }^{4}$ The authorities said the surplus would likely be considerably higher than budgeted, noting gains from efforts to improve tax compliance and continued constraints in implementing budgeted capital spending. They intend to propose a surplus in 2008/09 that is similar to this year's legislated budget.

8. In recent years the authorities have met three of their principal fiscal goals by maintaining surpluses in the overall and non-investment balances ${ }^{5}$ and limiting public expenditures to less than 40 percent of GDP. Staff and authorities agreed that a strong and

\footnotetext{
${ }^{4}$ This surplus, if achieved through stronger recurrent revenues or spending restraint, would bring the overall balance close to a longer-term sustainable level (discussed later).

${ }^{5}$ The non-investment balance equals the difference between non-mineral revenues and current expenditures excluding those for education and health.
} 
stable fiscal position and high-quality capital spending would help produce growth, low inflation and a stable REER. The non-investment surplus goal emphasizes the importance of preserving the net wealth of the government by avoiding the use of nonrecurring mineral revenues for recurring expenses and using them instead for capital spending (here defined to include investment in human capital via public education and health). ${ }^{6}$ However, the noninvestment balance has drawbacks. It suggests, for instance, that human and physical capital expenditures are one-off investments, despite the need to replace and expand infrastructure.

\section{Staff recommended that, in addition to their current fiscal goals, the authorities}

in the NDP 10 target a reduction in the non-mineral primary deficit. This balance, which excludes revenues from nonrenewable resources and also interest spending and receipts, can provide a measure of longer-term fiscal sustainability. A high non-mineral primary deficit is not sustainable once mineral resources are exhausted. But like the non-investment balance, this does not address what level of capital spending is optimal. If spending were sufficiently productive to eventually yield faster future growth of recurrent revenues, a larger nonmineral deficit would be sustainable.

\section{Staff proposed benchmarking a sustainable level of the primary non-mineral} deficit (and hence spending) based on the notion of "permanent income" (Box 1). Using staff assumptions about the growth of recurrent spending and mineral availability, the permanent income calculation indicates that the spending ceiling should be reduced from 40 percent of GDP to 30 percent, ${ }^{7}$ which is close to the estimated outcome for $2006 / 07$. Any relaxation of share of spending in GDP relative to last year's outcome should be justified on the grounds that these expenditures have a rate of return for the government higher than that on financial savings. The authorities indicated that in view of their ambitious capital spending objectives and other social needs, and their confidence in the attendant growth of recurrent revenues, they would adhere to the spending ceiling of 40 percent of GDP. They are currently developing the macroframework for NDP 10.

\footnotetext{
${ }^{6}$ A number of countries, including the United Kingdom, have adopted a similar kind of indicator, sometimes termed the "golden rule."

${ }^{7}$ This assumes that spending is limited to non-mineral revenues (assumed to increase from the current 22 percent of GDP to around $23 \frac{1}{2}$ percent in 2010/11) and annuitized mineral revenue of about $6 \frac{1}{3}$ percent of GDP.
} 


\section{Box 1. Calculating Fiscal Sustainability Benchmarks for Botswana}

The permanent income hypothesis suggests that Botswana should not spend more than the "permanent" part of its mineral revenues, saving the rest. The return on these savings would help sustain fiscal spending once diamonds are depleted. To compute permanent income, the projected stream of mineral revenues is transformed into a hypothetical expected annuity. It is assumed that diamond production sharply declines around 2021 but that an annuity using wealth from diamonds will last until 2050 (a realistic time horizon given uncertainty regarding resource discoveries and the growth of nonmineral revenues); the annuitized mineral revenue is modeled to stay constant in terms of GDP. ${ }^{1}$ The permanent income then equals the sum of non-mineral revenues plus the annuity. The benchmarked balances are the result of setting annual expenditures equal to the permanent income and saving the difference between actual and the hypothetical annuitized mineral revenues (Text Figure).

Botswana: Mineral Revenues, Annuity, and Asset Accumulation (Percent of GDP)

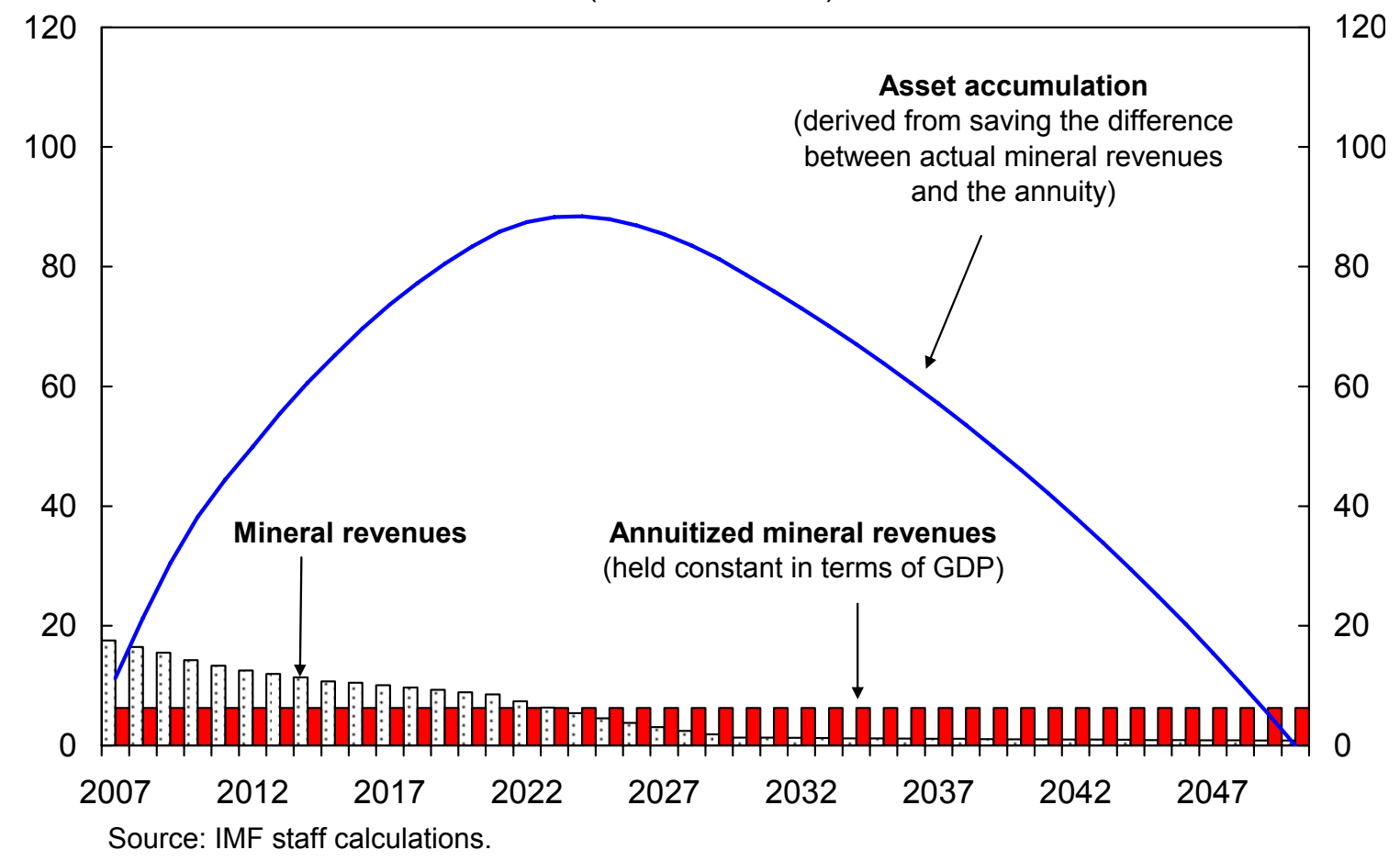

The benchmarked balances suggest that continued fiscal restraint is needed to achieve fiscal sustainability. The benchmarked non-mineral balance derived from permanent income suggests a lower deficit in 2007 and 2015 (corresponding to a higher overall surplus) compared to the projected balancewith the exception of scenario (c) (see Table below). The higher the assumed return on savings and the greater the mineral deposits, the lower the benchmarked fiscal adjustment needed for sustainability.

These illustrative calculations are derived from a social welfare function that assumes that it is socially optimal to smooth expenditure over time, which seems reasonable for a middle-income country. However, spending more of the mineral revenues upfront could increase social welfare (depending on the social welfare function, composition of spending, and rate of return of public investment). The marginal benefit from spending should be greater than the returns on financial assets.

\footnotetext{
${ }^{1}$ See more details in Chapter 1 of the accompanying Selected Issues Papers.
} 
Medium-Term Fiscal Outlook and Sustainability Benchmarks

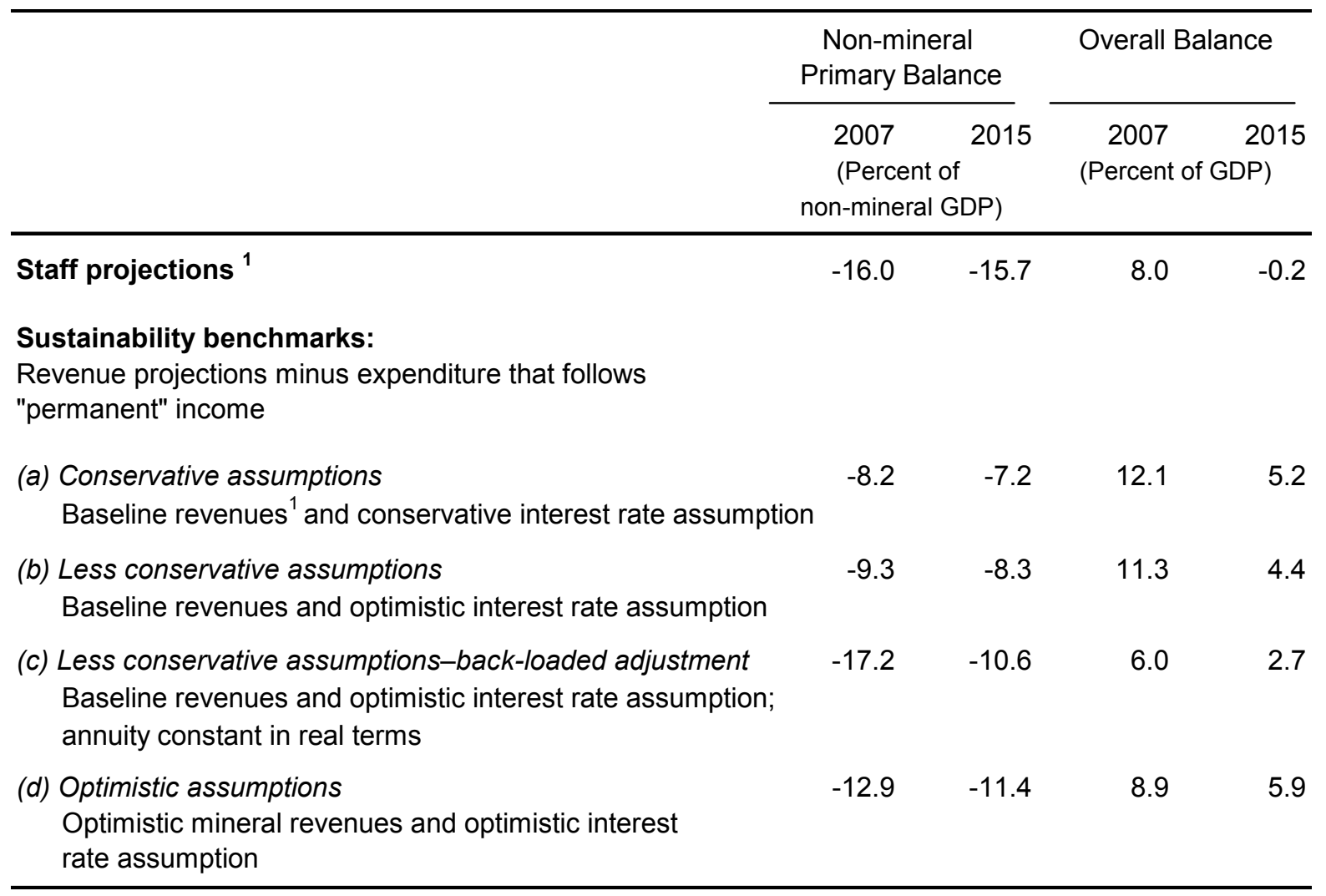

Source: IMF staff calculations.

${ }^{1}$ Revenue projections assume a slow increase in non-mineral revenues and a decrease in mineral revenues in terms of GDP. Expenditure projections assume that capital expenditure and expenditure on health and other critical areas increase in terms of GDP.

(a) The conservative interest rate assumption refers to a nominal interest interest rate of around $73 / 4$ percent that corresponds to a real interest rate of 3 percent. The past rates of return on the Pula Fund are unknown. In comparison, the Norwegian Government Pension Fund has earned an annualized net real return of 4.6 percent since 1997.

(b) The optimistic interest rate assumption refers to a nominal interest interest rate of around $91 / 4$ percent that corresponds to a real interest rate of about $4 \frac{1}{2}$ percent. Being more optimistic concerning the return on assets allows for somewhat larger non-mineral deficits and lower overall balances relative to (a).

(c) Programming the annuity to stay constant in real terms (rather than in terms of GDP) yields lower initial savings as suggested by the benchmarks. Thus, this scenario assumes a more back-loaded adjustment.

(d) Assuming a slower decline in the path of mineral revenues changes the value of the annuity and thereby allows for higher non-mineral deficits relative to (b). 
11. The authorities agreed that increasing non-mineral revenues is essential. The creation of the Botswana Unified Revenue Service has unified and reinforced administration of the value-added tax (VAT) and income taxes. Higher cost recovery in parastatal utilities is helping consolidate the fiscal position and may spur efficiency in services. The authorities agreed with staff that if mineral revenues or SACU receipts decline, raising the VAT rate to the regional norm could be one option for offsetting the revenue losses. ${ }^{8}$

12. Continued rationalization of public spending is also a government priority. Staff agreed with the authorities that the comprehensive review of public sector wages that is nearing completion should be used to rationalize wage policies. Raising public sector productivity is a high priority for the government, motivating the recent reorganization of the Ministry of Finance, and would create room for anticipated increases in investment and HIV/AIDS-related spending.

\section{Staff noted that the creation of an explicit sovereign wealth fund could have} benefits. It could strengthen support for fiscal savings by underscoring the link between fiscal surpluses now and more stable spending in the future when diamond revenues decline. ${ }^{9}$ A fund could also emphasize the importance of formulating a comprehensive plan for management of sovereign wealth and make more clear the high costs of liquidity control. However, improvements to transparency and the institutional framework, for instance, by limiting transfers of Pula Fund assets to the Liquidity Portfolio or the use of income on assets, could also be achieved with the current arrangements of the Pula Fund as part of the BoB balance sheet. The authorities indicated that they have elected to preserve the existing institutional arrangements, noting that current arrangement for Pula Fund management gives them flexibility to maneuver in case of possible simultaneous large external shocks, an important consideration given the concentration of export earnings.

\section{B. Monetary and Exchange Rate Policies to Control Inflation, Maintain Competitiveness, and Respond Flexibly to Shocks}

\section{Staff and the authorities agreed that since the devaluations in 2004 and 2005 the} policy mix of fiscal restraint, tight monetary policy and the crawling peg exchange rate

\footnotetext{
${ }^{8}$ The Southern African Development Community Free Trade Act is expected to come into effect in August 2008 but is not expected to have any significant immediate revenue consequences for Botswana.

${ }^{9}$ Such funds are being considered by several middle-income countries accumulating financial assets and have been implemented in Chile and Trinidad and Tobago. The Pula Fund has some features of a sovereign wealth fund in that it seeks to diversify and increase national wealth. However, it is institutionally part of the BoB balance sheet and thus its assets can be transferred to the Liquidity Portfolio (a tranche of Botswana's international reserves) and revenues from the Pula Fund currently offset losses incurred from monetary policy operations (Botswana: Financial Sector Stability Assessment, 2007, Box 2).
} 
regime has stabilized the REER, bringing inflation down. Current monetary policy targets a specific range for inflation, and exchange rate policy also seeks REER stability. Staff noted that simultaneous achievement of these objectives will not be easy; in a small, open economy, it is not possible to set the nominal exchange rate, the inflation rate, and the real exchange rate independently for long. The choice of a nominal anchor should be guided by the characteristics of the economy, the nature of likely shocks, and the relative strength of foreign and domestic determinants of inflation. An inflation objective is a possible anchor for Botswana but achieving it would require some nominal exchange rate flexibility in case of external shocks. ${ }^{10}$ Staff therefore recommended that the authorities consider setting a firmer legal foundation for the price stability objective, consistent with international and regional trends, by amending the BoB Act.

15. The authorities indicated that they consider a stable REER to be critical. In their view, the REER in the past year reached a level conducive to economic diversification. They also noted that structural reforms should address obstacles to competitiveness in the nonmining sector. The staff analysis suggests that the exchange rate is at about its equilibrium value in terms of past trends in its determinants (Box 2 and Table 11). However, a forwardlooking assessment, taking into account the need to accumulate savings to sustain imports after diamond production falls, suggests that slightly larger current account surpluses would be needed. Moreover, alternative REER indices and structural competitiveness indicators point to continued need to improve labor productivity and competitiveness.

\footnotetext{
${ }^{10}$ Botswana's open economy and reliance on diamonds suggest that both real and monetary shocks are potentially significant, weighing in favor of and against, respectively, a nominal inflation anchor. In addition, foreign determinants of inflation are significant, while domestic determinants somewhat mitigated, but further empirical study is required.
} 


\section{Box 2. Botswana: Exchange Rate Assessment}

This assessment relies on three different but complementary approaches ${ }^{1}$ :

- An econometric analysis of behavioral determinants of the equilibrium real effective exchange rate (EREER) - namely the real interest rate differential between Botswana and trading partners; the terms of trade; government consumption; and relative productivity against main trading partners - indicates that by 2006 Botswana's REER was roughly in line with its equilibrium value (Box Figure 1).

- A forward-looking assessment of external sustainability highlights the need for current account surpluses to sustain imports and domestic consumption beyond the horizon of diamond production. The sustainable current account balance is computed similarly to fiscal sustainability benchmarks: as the difference between mineral exports and the annuity value of projected mineral exports. Baseline assumptions for the financial account and external indebtedness are as summarized in the debt sustainability analysis. The results show that the current account is close to or slightly below its long-
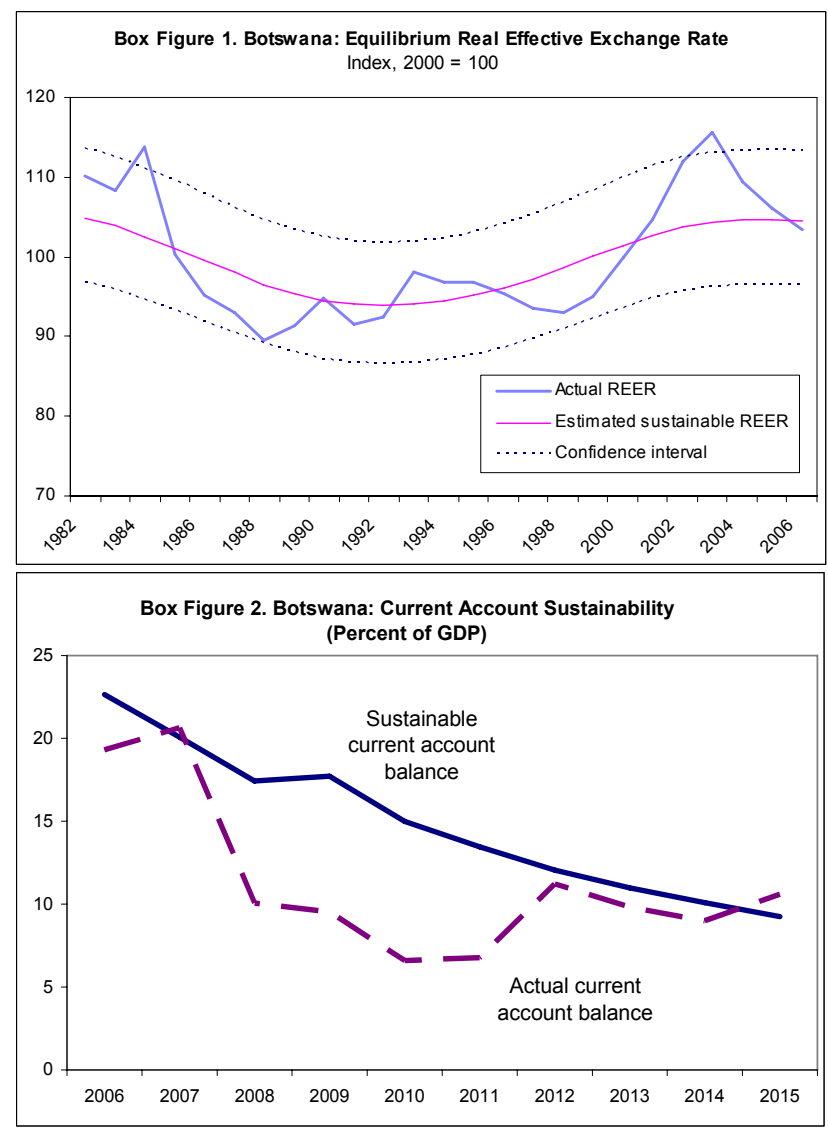
run sustainable value, suggesting a small overvaluation. Projected lower surpluses in 2007-11 reflect imports for infrastructure and mining projects. Sensitivity analysis indicates that a lower discount rate or lower diamond exports would increase the gap between the projected and sustainable current account (Box Figure 2).

- An analysis of economic indicators indicates that the REER overvaluation from 2000-2004 mainly resulted from a pronounced dip in productivity relative to trading partners (Box Figure 3). The 2004 and 2005 devaluations and move to a crawling peg have more than reversed the overvaluation in the CPI-based REER and have boosted export profitability, especially in non-mining sectors. However, productivity gains have been modest, especially relative to trading partners, while export volume growth has slowed and the share of exports of goods and services in GDP has remained flat. The relative productivity trends and competitiveness rankings suggest that measures to improve labor productivity and the business environment are crucial for diversification.

\footnotetext{
${ }^{1}$ See more details in Chapter 2 of the accompanying Selected Issues Papers.
} 
Box Figure 3. Botswana: Exchange Rates and Export Patterns (concluded)

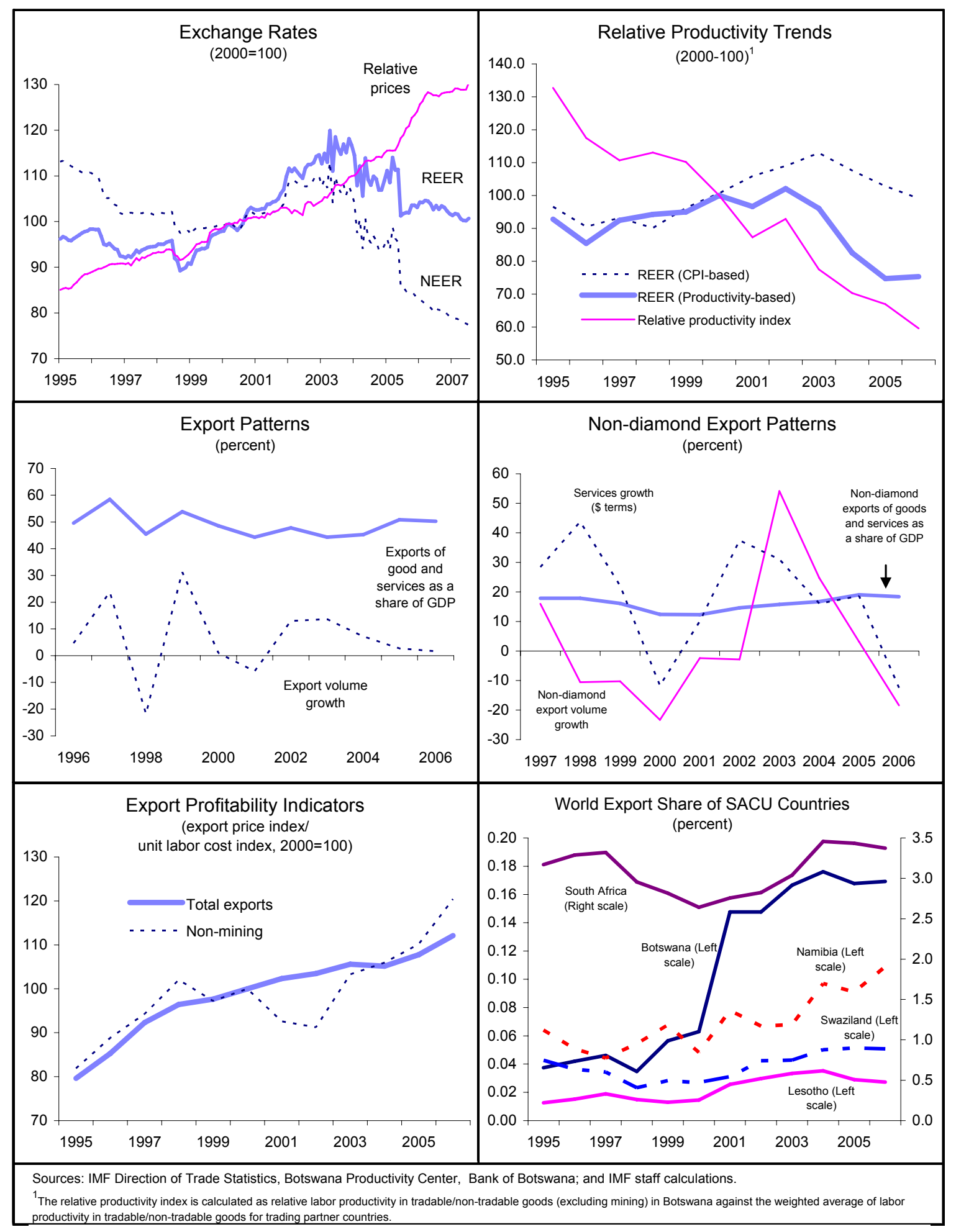


16. The debt sustainability analysis shows little risk of debt distress. It indicates Botswana's external debt would remain below 50 percent of GDP in the stress-test scenarios (Appendix).

17. Maintaining an appropriate balance between exchange rate and monetary policy objectives will be critical for building the non-diamond sectors. The recent combination of lowering the policy interest rate and slowing the rate of crawl was appropriate, because containing inflation has come at the cost of high real interest rates that deter lending. Further slowing of the rate of crawl will help reduce inflationary pressures and facilitate additional gradual reduction of interest rates, which will support non-mineral activities while relieving pressures on the BoB balance sheet. The still low ratio of credit to GDP suggests considerable scope for noninflationary monetary deepening.

18. Staff noted that systemic excess liquidity is impeding the development of interbank markets and has weakened the monetary policy transmission mechanism. While improvements in treasury cash management, the channeling of a significant part of diamond receipts directly to the $\mathrm{BoB}$, and supporting reforms have reduced liquidity, the growth of the BoBC stock continues to raise concerns. Staff therefore welcomed the authorities' intention to roll over the medium-term government bond due in 2008 and encouraged them to consider the FSAP recommendations to further streamline liquidity management within the $\mathrm{BoB}$ and build the domestic bond market by regular issuance of government bonds, which would also help create a meaningful yield curve.

\section{Financial and Structural Reforms}

\section{Botswana's generally sound financial sector is seeking to meet international} norms, as the FSAP shows. Short-term risks appear to be contained and banking sector prudential indicators are sound. Botswana is generally observing international standards in transparency of monetary and financial policies, banking supervision, and payments systems, and has begun to strengthen oversight of the NBFIs. The recent growth in unsecured household credit and in collateralized mortgages, which has outpaced growth in business lending, represents a significant untested risk, though asset quality measures are currently satisfactory and banks are improving credit risk analysis. ${ }^{11}$

20. Staff believe that Botswana's macroeconomic policies provide a conducive environment for building on the strengths of the banking sector and addressing financial sector weaknesses. Financial sector reform is critical for supporting successful economic diversification and non-diamond growth. Staff welcomed the authorities' engagement in the FSAP, and their continuing solid commitment to consider its recommendations.

11 Botswana: Financial Sector Stability Assessment, 2007 discusses in more detail capital market developments. 


\section{Staff urged the authorities to give priority to:}

- Drawing up a comprehensive financial sector strategy reform plan using a high-level committee to guide and monitor the reform process;

- Getting the NBFI Regulatory Authority running, as planned, by the target of January 2008 (Box 3);

- Further strengthening the BoB's powers to supervise statutory banks and banking groups and improving cooperation between the $\mathrm{BoB}$ and domestic and cross-border supervisors in neighboring countries;

- Improving access to financial services by reforming the panoply of public financial institutions through privatization and other means; and

- Continuing to take steps to implement the Financial Action Task Force (FATF) recommendations on anti-money-laundering and combating the financing of terrorism (AML/CFT), and setting up the Financial Intelligence Unit.

\section{Box 3. Botswana: Reform of the Nonbank Financial Institutions-Financial Sector Assessment Program Findings}

The authorities have embarked on a plan to upgrade the regulatory system of the NBFIs. A new NBFI Regulatory Authority Act establishes a single NBFI regulatory agency and provides a more effective platform for supervision and regulation of NBFIs.

The FSAP underlines implementation challenges. The legal reform agenda is extensive, and there is a need to improve basic reporting and regulatory surveillance of the NBFIs. The FSAP has stressed the need to begin the oversight of pension fund administrators and asset managers and to monitor the foreign asset holdings, which currently stand at around 65 percent of total pension fund assets. The oversight of the insurance sector also needs strengthening through analysis of statutory returns and regulations on intermediaries and issuance of market conduct guidelines

The NBFIs could play an important role in developing local financial markets. Meeting the needs of pension funds to hedge their offshore investments, for example, would offer opportunities to create futures and forward markets. Botswana's potential to develop into a regional financial center where regional governments and corporates may raise capital to finance growth depends upon establishing a benchmark yield curve.

\section{Staff noted that structural reforms are essential to increase productivity,} promote diversification and job creation, and improve policy analysis. The authorities are making welcome efforts to facilitate expansion of downstream diamond and copper activities and investments to address the regional power shortage will promote diversification. The authorities should move ahead with privatization of the large parastatals as soon as an appropriate regulatory framework is in place. Improving the skills match through reform of education and vocational training is an important goal.

23. Strengthening the investment climate must continue to be a priority. Recent government initiatives to improve the investment climate, especially the new foreign direct 
investment strategy and competition policy, are welcome. The authorities commented that they have implemented a number of Foreign Investment Advisory Service (FIAS), including sharply reducing the time needed to register a new business, acquire a business license, and get connected to utilities. They also stressed their commitment to addressing concerns about access to land and work and residence permits for expatriates.

24. Administered prices for a range of non-tradables may lead to market distortions and cloud the monetary transmission mechanism. Staff and the authorities agreed that it would be useful to liberalize prices by instituting more regular price adjustments linked to market developments.

25. Botswana's economic statistics are generally adequate for surveillance, but the recent Data Quality Assessment and Data Report on the Observance of Standards and Codes (ROSC) found weaknesses in all key sectors. The authorities have indicated a strong interest in upgrading their statistical capacities and currently participate in the General Data Dissemination System (GDDS). A successful transformation of the Central Statistical Office into an autonomous agency with more skilled staff will make it easier for government to formulate good policy.

\section{Staff Appraisal}

26. Recent economic developments have been positive, and the medium term looks bright. Non-diamond growth is expected to remain strong and diamond production seems likely to continue at roughly its current level. Inflation has fallen substantially, though it is still at risk. High mineral prices are contributing to solid fiscal and balance of payments surpluses; continued and prospective development of minerals and significant investment in electricity generation are projected to sustain fiscal and balance of payments surpluses through 2011. The most obvious risk is the possibility that diamond prices will drop.

27. Although diversification is progressing, a faster move away from diamonds is needed to address the sharp decline in diamond production that may occur after 2020. A number of promising projects are on the horizon, but the next NDP will need to reinforce the framework for non-mineral growth.

28. Maintaining fiscal surpluses over the medium term is essential to accumulate savings for the period when diamond revenues decline. Maintaining expenditures at about 30 percent of GDP, as in 2006/07, and continuing efforts to build non-diamond revenues will strengthen fiscal sustainability.

29. Creation of an explicit sovereign wealth fund could be considered. It could help to galvanize greater support for running fiscal surpluses to smooth the benefits from diamond revenues over the longer term. It could also lead to an improved institutional framework for managing government financial assets, though improvements in transparency and the institutional framework can be achieved with the Pula Fund remaining within the BoB. 
30. Striking an appropriate balance between monetary and exchange rate policy objectives is critical. Devaluation provided a competitive boost to exports, but the associated high interest rates have raised the cost of capital. Reducing the nominal interest rate and slowing the rate of crawl were appropriate, and further slowing of the crawl, consistent with narrowing inflation differentials, will allow additional scope for interest rate reductions. The REER has stabilized in the past year at close to its equilibrium value.

31. The banking sector is sound and near-term risks are well contained, as the FSAP found, but there is still a sizable agenda for financial sector reform. An important priority is to initiate the NBFI Regulatory Authority by January 2008 and complete the legislative agenda for pension and insurance reform.

32. Continued structural reform and improvements in statistics are also essential.

Privatization, properly regulated; reducing the skills mismatch through education reform; and further improvements in the business environment, especially completing the drafting of an effective foreign direct investment strategy and competition policy, will help raise productivity and attract investment. Stronger growth in the non-mineral economy will also generate employment. Liberalizing administered prices will enhance efficiency, and further development of the statistical data base will support sound policy analysis.

33. Botswana has not enacted any restrictions on the making of payments and transfers for current international transactions since its last Article IV consultation and in August 2007 it removed its one multiple currency practice.

34. It is recommended that the next Article IV consultation be held on the standard 12-month cycle. 
Figure 1. Growth

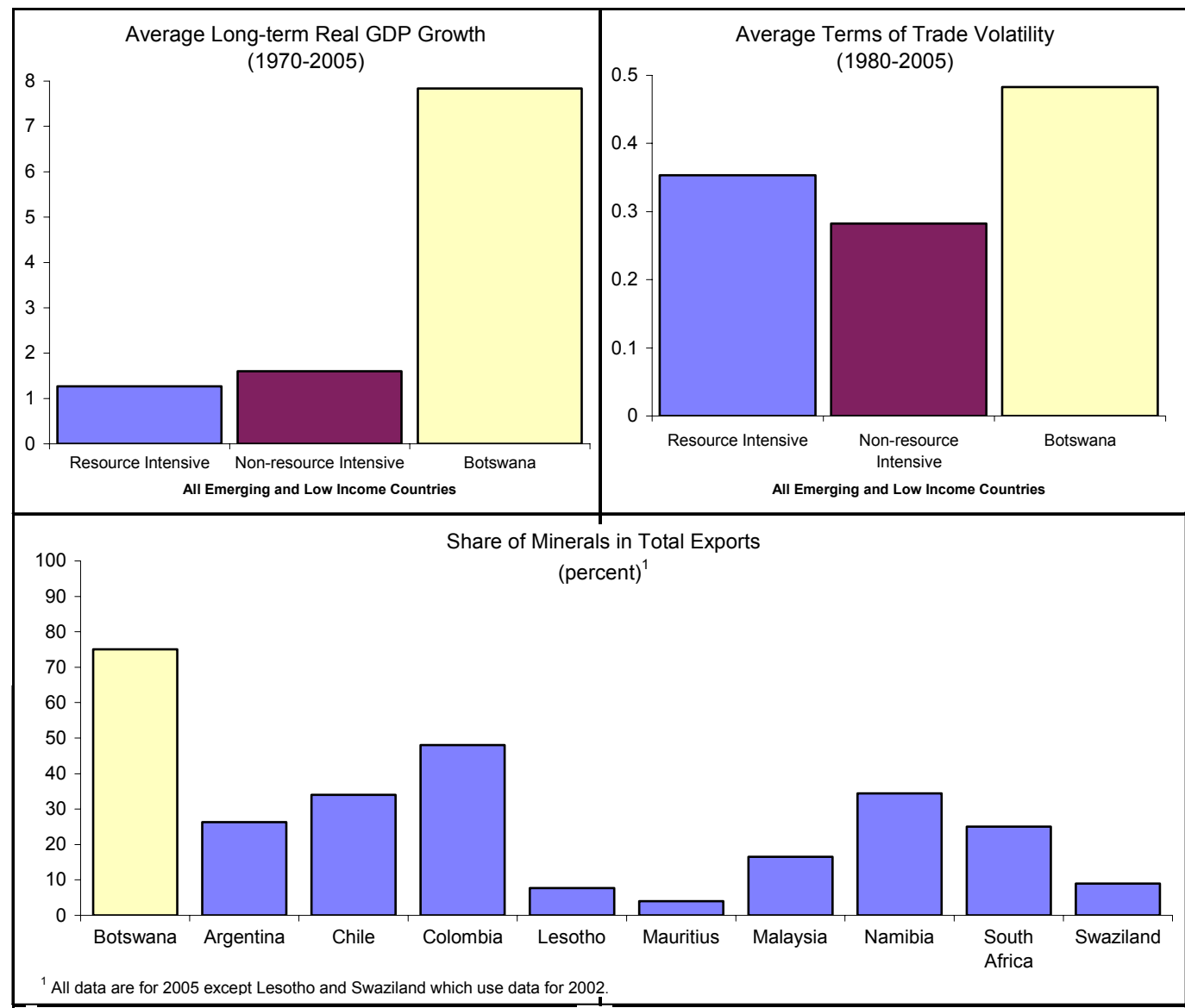

Sources: UN COMTRADE Database, Bank of Botswana; and IMF staff calculations. 
Figure 2. Real Sector and Monetary Developments

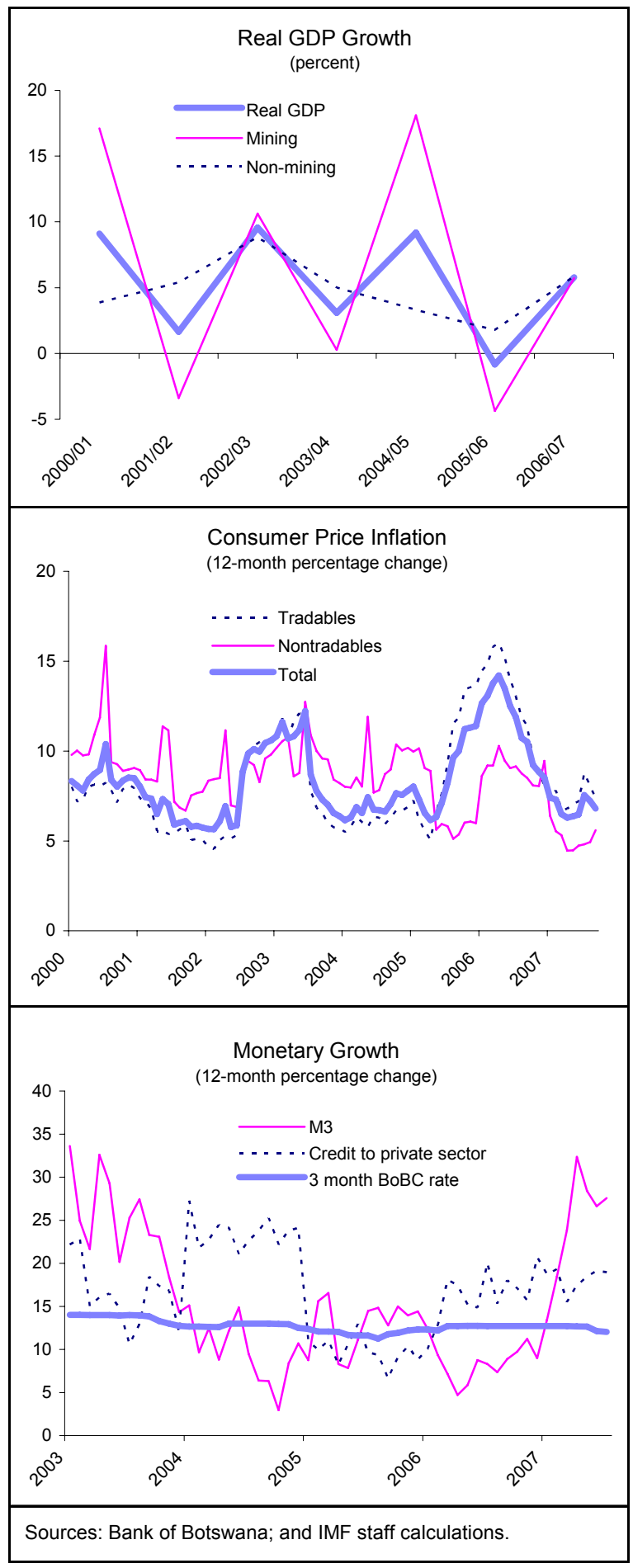


Figure 3. Fiscal Developments

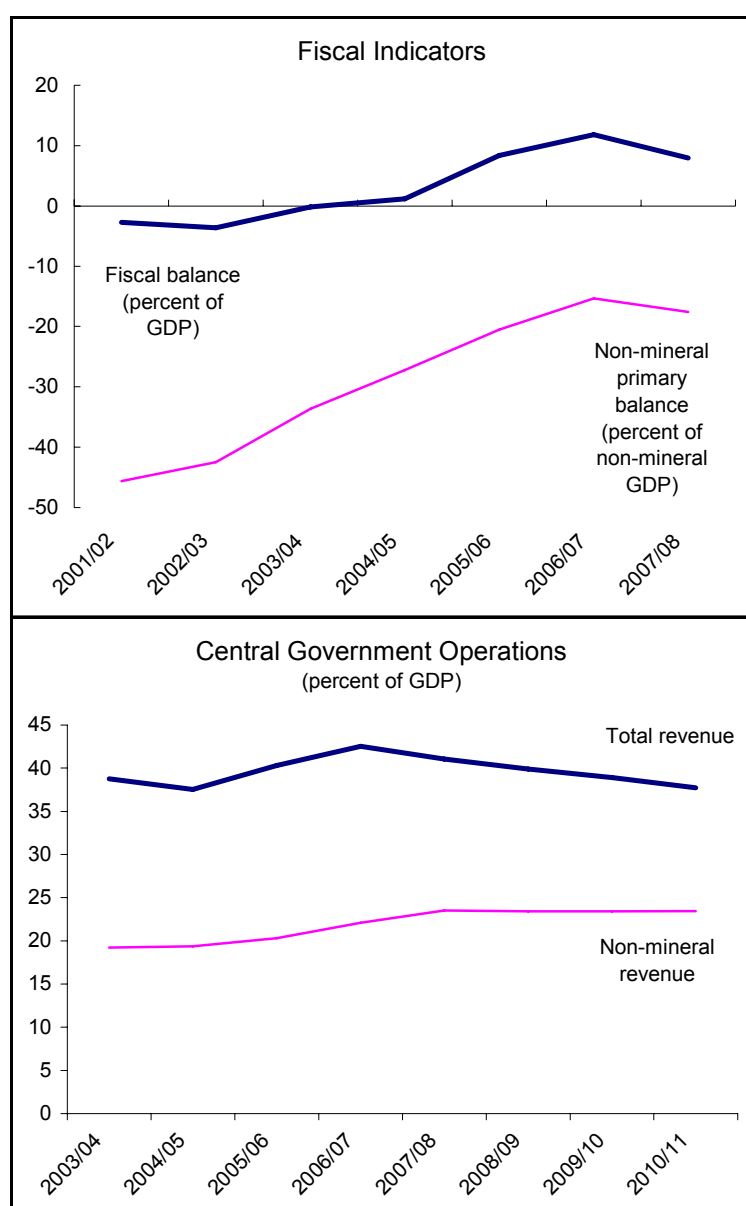

Central Government Operations (percent of GDP)

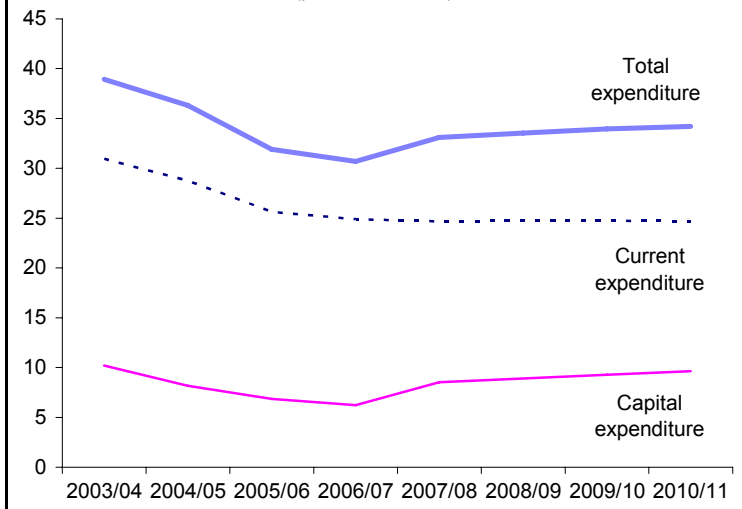

Sources: Ministry of Finance and Development Planning; and IMF staff calculations. Data through 2006 are historical and from 2007 onwards are forecasts. 
Figure 4. External Sector Developments

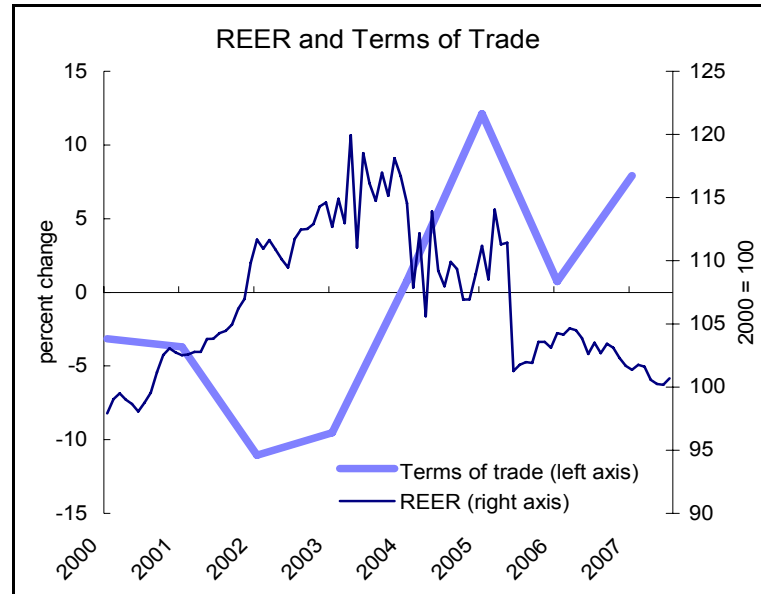

Balance of Payments (percent of GDP)

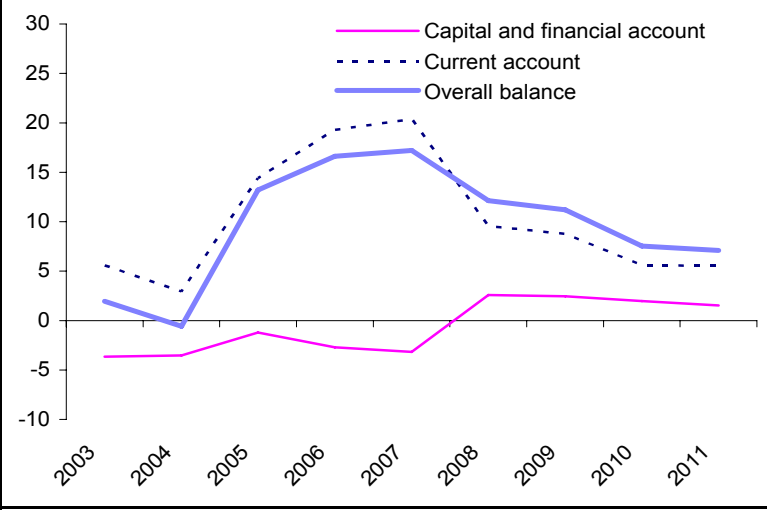

Foreign Exchange Reserves (in months of prospective imports of

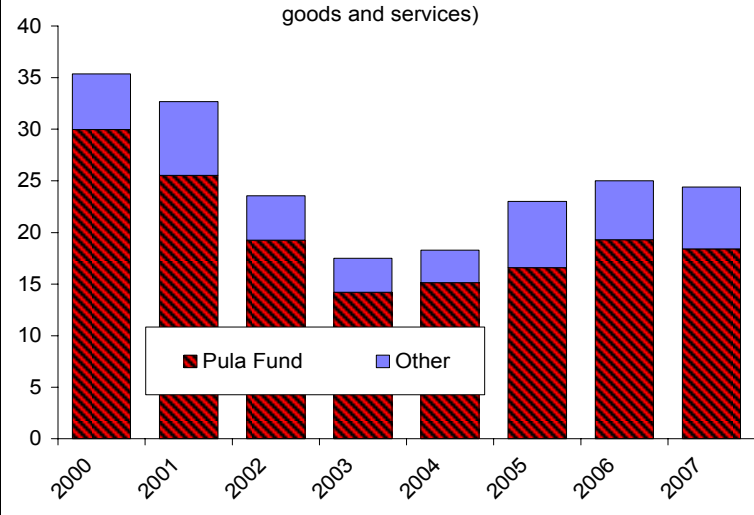

Sources: Bank of Botswana; and IMF staff calculations. Data through 2006 are historical and from 2007 onwards are forecasts. 


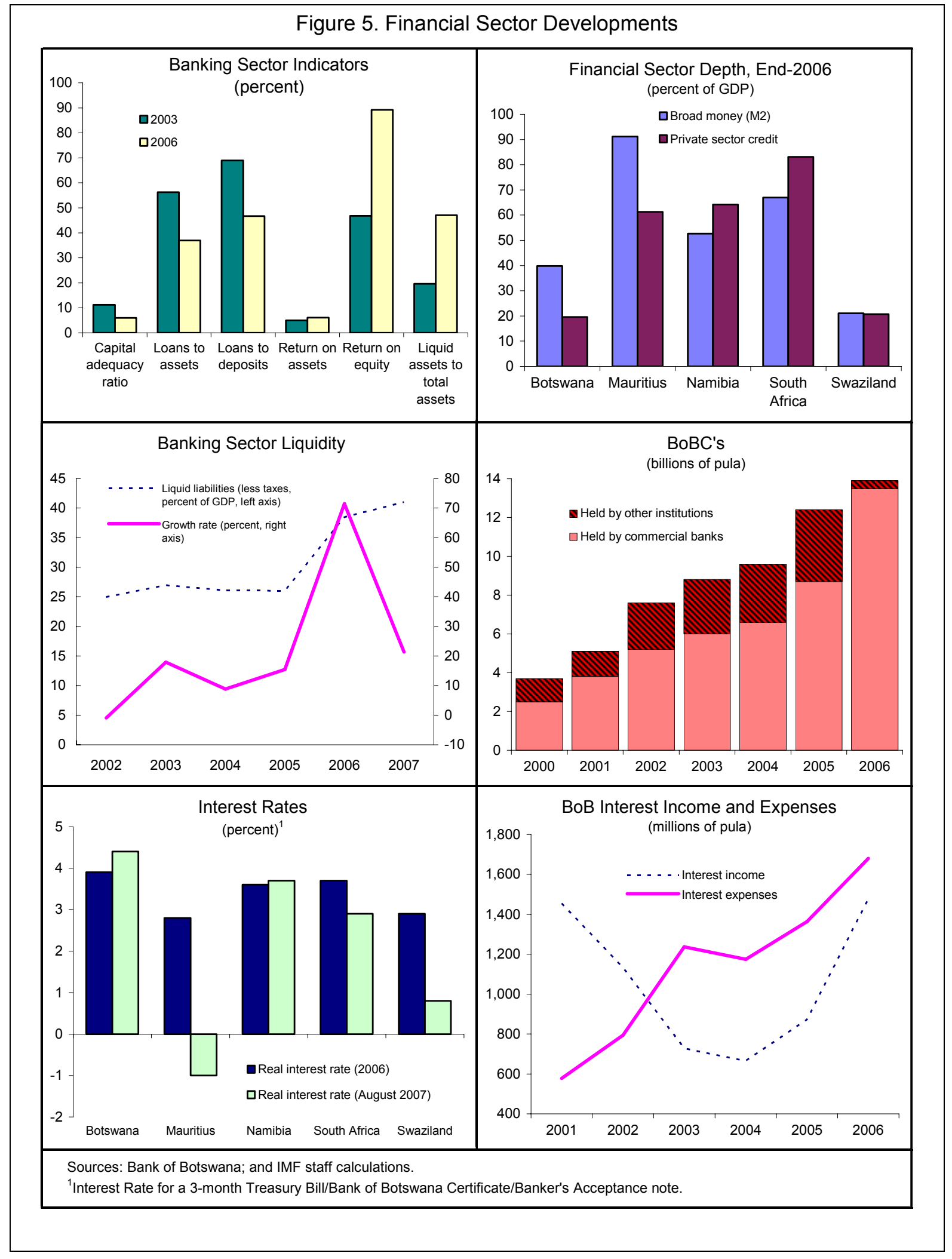


Table 1a. Comparative Social Indicators, 2005

\begin{tabular}{|c|c|c|c|c|c|c|c|}
\hline Country & $\begin{array}{l}\text { GNI per Capita, } \\
\text { (Atlas method, } \\
\text { US\$) }\end{array}$ & $\begin{array}{l}\text { Total Life } \\
\text { Expectancy } \\
\text { at Birth } \\
\text { (years) } \\
\end{array}$ & $\begin{array}{l}\text { Infant Mortality } \\
\text { Rate (per } 1,000 \\
\text { live births) }\end{array}$ & $\begin{array}{c}\text { Prevalence of HIV } \\
\text { (percent of population } \\
\text { ages 15-49) }\end{array}$ & $\begin{array}{c}\text { Primary School } \\
\text { Enrollment (net } \\
\text { percent) }\end{array}$ & $\begin{array}{l}\text { Primary School } \\
\text { Completion Rate } \\
\text { (percent of relevant } \\
\text { age group) }\end{array}$ & $\begin{array}{c}\text { Population } \\
\text { Growth } \\
\text { (percent) }\end{array}$ \\
\hline Botswana ${ }^{1}$ & 5,590 & 56.0 & 56 & 17.1 & 95.3 & 92.0 & 2.3 \\
\hline Chile & 5,870 & 78.1 & 8 & 0.3 & $\ldots$ & 98.1 & 1.1 \\
\hline Lesotho & 950 & 35.2 & 102 & 23.2 & 86.7 & 66.9 & -0.2 \\
\hline Malaysia & 4,970 & 73.7 & 10 & 0.5 & 96.9 & $\ldots$ & 1.8 \\
\hline Mexico & 7,310 & 75.3 & 22 & 0.3 & 97.6 & 97.0 & 1.0 \\
\hline Namibia & 2,990 & 46.9 & 46 & 19.6 & 72.2 & 75.3 & 1.1 \\
\hline Poland & 7,160 & 74.9 & 6 & 0.1 & 96.6 & 95.3 & 0.0 \\
\hline South Africa & 4,770 & 47.7 & 55 & 18.8 & $\ldots$ & $\ldots$ & 1.1 \\
\hline Swaziland & 2,280 & 41.5 & 110 & 33.4 & $\ldots$ & $\ldots$ & 1.0 \\
\hline Sub-Saharan Africa & 746 & 46.6 & 96 & 5.8 & 56.6 & 50.7 & 2.3 \\
\hline Upper middle income & 5,533 & 69.8 & 22 & 2.2 & $\ldots$ & $\ldots$ & 0.6 \\
\hline World & 7,011 & 67.6 & 51 & 1.0 & $\ldots$ & $\ldots$ & 1.2 \\
\hline
\end{tabular}

Source: World Development Indicators database, 2007.

${ }^{1}$ For Botswana, the data on HIV prevalance are from the National AIDS Coordinating Agency, BAIS II, 2004 and are for the entire population aged 18 months and above; data on life expectancy, infant mortality, primary school enrollment, and population growth are from the Botswana Millennium Development Goals, Status Report, 2004.

Table 1b. Income Distribution, Poverty, and Unemployment

\begin{tabular}{|c|c|c|c|c|}
\hline Country & $\begin{array}{l}\text { GNI per Capita (Atlas } \\
\text { method, US\$) }\end{array}$ & Gini Coefficient $^{1}$ & Poverty $^{2}$ & Unemployment $^{3}$ \\
\hline & & & \multicolumn{2}{|c|}{ (Percent) } \\
\hline Botswana & 5,590 & 63 & 30 & 18 \\
\hline Chile & 5,870 & 57 & $<2$ & 7 \\
\hline Lesotho & 950 & 63 & 36 & $\ldots$ \\
\hline Malaysia & 4,970 & 49 & $<2$ & 4 \\
\hline Mexico & 7,310 & 50 & 5 & 3 \\
\hline Namibia & 2,990 & 74 & 35 & 31 \\
\hline Poland & 7,160 & $\ldots$ & $\ldots$ & 18 \\
\hline South Africa & 4,770 & 58 & 11 & 28 \\
\hline Swaziland & 2,280 & 61 & $\ldots$ & $\ldots$ \\
\hline Sub-saharan Africa & 746 & $\ldots$ & 44 & $\ldots$ \\
\hline Upper middle income & 5,533 & $\ldots$ & $\ldots$ & 12 \\
\hline World & 7,011 & $\ldots$ & $\ldots$ & $\ldots$ \\
\hline
\end{tabular}

Source: World Bank, World Development Indicators 2007.

Note: Most of the data refer to 2005.

${ }^{1}$ A measure of distribution of income, where 0 represents perfect equality and 100 represents perfect inequality. For Botswana, the figure represents cash income only.

${ }^{2}$ Poverty at below $\$ 1 /$ day PPP basis. The figure for Botswana is from a 2002-2003 HIES using the country's poverty datum line which is higher than the $\$ 1 /$ day PPP basis.

${ }^{3}$ The figure for Botswana is from the 2005-2006 Labour Force Survey. 
Table 1c. Millennium Development Goals

\begin{tabular}{|c|c|c|c|c|c|}
\hline & 1990 & 1995 & 2000 & 2005 & $\begin{array}{l}2005 \\
\text { SSA }^{1}\end{array}$ \\
\hline \multicolumn{6}{|l|}{ Goal 1: Eradicate extreme poverty and hunger } \\
\hline Income share held by lowest 20 percent & $\ldots$ & 3.2 & $\ldots$ & $\ldots$ & $\ldots$ \\
\hline Malnutrition prevalence, weight for age (percent of children under 5) & $\ldots$ & 17.2 & 12.5 & $\ldots$ & $\ldots$ \\
\hline Poverty gap at $\$ 1$ a day (PPP) (percent of population) & $\ldots$ & 9.9 & $\ldots$ & $\ldots$ & $\ldots$ \\
\hline Poverty headcount ratio at $\$ 1$ a day (PPP) (percent of population) & $\ldots$ & 28.0 & $\ldots$ & & $\ldots$ \\
\hline Poverty headcount ratio at national poverty line (percent of population) ${ }^{2}$ & $\ldots$ & $\ldots$ & $\ldots$ & 30.0 & $\ldots$ \\
\hline Prevalence of undernourishment (percent of population) & 23.0 & 27.0 & $\ldots$ & 32.0 & 29.6 \\
\hline \multicolumn{6}{|l|}{ Goal 2: Achieve universal primary education } \\
\hline Literacy rate, youth total (percent of people ages 15-24) & 83.0 & $\ldots$ & $\ldots$ & 94.0 & $\ldots$ \\
\hline Persistence to grade 5 , total (percent of cohort) & 84.0 & $\ldots$ & 89.0 & 90.0 & $\ldots$ \\
\hline Primary completion rate, total (percent of relevant age group) & 76.0 & 87.0 & 87.0 & 92.0 & $\ldots$ \\
\hline School enrollment, primary (percent net) ${ }^{3}$ & 83.0 & $\ldots$ & 80.0 & 95.3 & 66.0 \\
\hline \multicolumn{6}{|l|}{ Goal 3: Promote gender equality and empower women } \\
\hline Proportion of seats held by women in national parliament (percent) & 5.0 & 9.0 & 17.0 & 11.0 & 16.0 \\
\hline Ratio of girls to boys in primary and secondary education (percent) & 108.0 & $\ldots$ & 101.0 & 102.0 & 86.0 \\
\hline Ratio of young literate females to males (percent ages 15-24) & 110.0 & $\ldots$ & & 104.0 & 88.0 \\
\hline $\begin{array}{l}\text { Share of women employed in the nonagricultural sector } \\
\text { (percent of total nonagricultural employment) }\end{array}$ & 33.5 & 38.4 & 40.2 & 43.0 & $\cdots$ \\
\hline \multicolumn{6}{|l|}{ Goal 4: Reduce child mortality } \\
\hline Immunization, measles (percent of children ages $12-23$ months) & 87.0 & 89.0 & 90.0 & 90.0 & 64.0 \\
\hline Mortality rate, infant (per 1,000 live births) ${ }^{3}$ & 45.0 & 50.0 & 74.0 & 56.0 & 96.0 \\
\hline Mortality rate, under-5 (per 1,000$)^{3}$ & 58.0 & 66.0 & 101.0 & 74.0 & 163.0 \\
\hline \multicolumn{6}{|l|}{ Goal 5: Improve maternal health } \\
\hline Births attended by skilled health staff (percent of total) & 78.0 & 87.0 & 94.0 & $\ldots$ & 45.0 \\
\hline Maternal mortality ratio (modeled estimate, per 100,000 live births) & $\ldots$ & $\ldots$ & 100.0 & $\ldots$ & $\ldots$ \\
\hline \multicolumn{6}{|l|}{ Goal 6: Combat HIVIAIDS, malaria, and other diseases } \\
\hline Contraceptive prevalence (percent of women ages 15-49) & 33.0 & $\ldots$ & 48.0 & 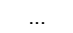 & $\ldots$ \\
\hline Incidence of tuberculosis (per 100,000 people) & 236.0 & 407.0 & 608.0 & 654.0 & 348.0 \\
\hline Prevalence of HIV, female (percent ages 15-24) & $\ldots$ & $\ldots$ & $\ldots$ & 15.3 & $\ldots$ \\
\hline Prevalence of HIV, total (percent of population ages $15-49)^{4}$ & $\ldots$ & $\ldots$ & $\ldots$ & 17.1 & 5.8 \\
\hline Tuberculosis cases detected under DOTS (percent) ${ }^{5}$ & $\cdots$ & 71.0 & 72.0 & 69.0 & 49.0 \\
\hline \multicolumn{6}{|l|}{ Goal 7: Ensure environmental sustainability } \\
\hline CO2 emissions (metric tons per capita) & 1.5 & 2.2 & 2.3 & 2.3 & 0.8 \\
\hline Forest area (percent of land area) & 24.0 & $\ldots$ & 22.0 & 21.0 & 26.5 \\
\hline $\begin{array}{l}\text { GDP per unit of energy use } \\
\text { (constant } 2000 \text { PPP \$ per kg of oil equivalent) }\end{array}$ & 6.2 & 6.2 & 7.3 & 8.6 & 2.8 \\
\hline Improved sanitation facilities (percent of population with access) & 38.0 & $\ldots$ & $\ldots$ & 42.0 & $\ldots$ \\
\hline Improved water source (percent of population with access) & 93.0 & $\ldots$ & $\ldots$ & 95.0 & 56.0 \\
\hline Nationally protected areas (percent of total land area) & $\ldots$ & $\ldots$ & $\ldots$ & 30.9 & 11.3 \\
\hline \multicolumn{6}{|l|}{ Goal 8: Develop a global partnership for development } \\
\hline Aid per capita (current US\$) & 102.0 & 55.0 & 17.0 & 40.0 & $\ldots$ \\
\hline $\begin{array}{l}\text { Debt service (PPG and IMF only, } \\
\text { percent of exports, excl. workers' remittances) }\end{array}$ & 4.3 & 3.1 & 2.0 & 0.9 & $\cdots$ \\
\hline Fixed line and mobile phone subscribers (per 1,000 people) & 18.0 & 37.0 & 192.0 & 541.0 & 142.0 \\
\hline Internet users (per 1,000 people) & 0.0 & 1.0 & 14.0 & 34.0 & 29.0 \\
\hline Personal computers (per 1,000 people) & $\ldots$ & 9.0 & 34.0 & 45.0 & 15.0 \\
\hline Total debt service (percent of exports of goods, services and income) & 4.3 & 3.1 & 2.0 & 0.9 & $\ldots$ \\
\hline Unemployment, youth female (percent of female labor force ages 15-24) & 33.4 & 42.4 & 14.0 & $\ldots$ & $\ldots$ \\
\hline Unemployment, youth male (percent of male labor force ages 15-24) & 20.2 & 33.5 & 13.2 & $\ldots$ & $\ldots$ \\
\hline Unemployment, youth total (percent of total labor force ages 15-24) & 25.6 & 37.9 & 13.6 & $\ldots$ & $\ldots$ \\
\hline \multicolumn{6}{|l|}{ Other } \\
\hline Fertility rate, total (births per woman) & 4.4 & 3.8 & 3.4 & 3.0 & $\ldots$ \\
\hline GNI per capita, Atlas method (current US\$) & 2,450 & 2,950 & 3,270 & 5,590 & $\ldots$ \\
\hline GNI, Atlas method (current US\$ billions) & 3.5 & 4.8 & 5.7 & 9.9 & $\ldots$ \\
\hline Gross capital formation (percent of GDP) & 37.4 & 24.6 & 34.2 & 31.5 & $\ldots$ \\
\hline Life expectancy at birth, total (years) ${ }^{3}$ & 64.0 & 57.0 & 43.0 & 56.0 & $\ldots$ \\
\hline Literacy rate, adult total (percent of people ages 15 and above) & 68.0 & $\ldots$ & $\ldots$ & 81.0 & $\ldots$ \\
\hline Population, total (millions) & 1.4 & 1.6 & 1.8 & 1.8 & $\ldots$ \\
\hline Trade (percent of GDP) & 104.8 & 89.0 & 86.3 & 85.3 & $\ldots$ \\
\hline
\end{tabular}

Source: World Development Indicators database, April 2007.

Note: Figures in italics refer to periods other than those specified.

${ }^{1}$ SSA represents the average for the sub-Saharan Africa region.

${ }^{2}$ Poverty headcount ratio at national poverty line updated from the Botswana 2002-2003 HIES

${ }^{3}$ Data taken from the Botswana Millennium Development Goals, Status Report, 2004.

${ }^{4}$ Data taken from the National AIDS Coordinating Agency, BAIS II, 2004 and are for the entire population aged 18 months and above.

${ }^{5}$ The Directly Observed Treatment, Short-course (DOTS) is a WHO-recommended strategy for detection and cure of TB. 
Table 2. Selected Economic and Financial Indicators, 2003-2007

\begin{tabular}{|c|c|c|c|c|c|}
\hline & 2003 & 2004 & 2005 & 2006 & 2007 \\
\hline & \multicolumn{5}{|c|}{ (Annual percentage change, unless otherwise indicated) } \\
\hline \multicolumn{6}{|l|}{ National income and prices } \\
\hline Real GDP ${ }^{1}$ & 3.1 & 9.2 & -0.8 & 5.8 & 4.3 \\
\hline Mineral & 0.3 & 18.1 & -4.4 & 5.7 & -4.3 \\
\hline Non-mineral & 5.0 & 3.3 & 1.8 & 5.8 & 10.4 \\
\hline Consumer prices (average) & 9.2 & 7.0 & 8.6 & 11.6 & 7.0 \\
\hline Consumer prices (end of period) & 6.4 & 7.9 & 11.3 & 8.5 & 7.4 \\
\hline Nominal GDP (billions of pula) ${ }^{1}$ & 42.6 & 49.6 & 57.1 & 66.5 & 74.3 \\
\hline Mineral & 15.1 & 19.2 & 22.2 & 26.9 & 28.7 \\
\hline Non-mineral & 27.5 & 30.4 & 35.0 & 39.6 & 45.6 \\
\hline \multicolumn{6}{|l|}{ External sector } \\
\hline Exports of goods and services, f.o.b. (US\$) & 29.3 & 20.9 & 20.5 & -0.3 & 12.6 \\
\hline \multicolumn{6}{|l|}{ Of which: } \\
\hline Diamonds & 20.0 & 18.0 & 19.7 & 1.0 & -1.9 \\
\hline Other raw materials & 57.5 & 14.8 & 141.8 & 41.7 & 53.0 \\
\hline Other & 84.8 & 44.1 & -12.7 & -26.2 & 66.2 \\
\hline Imports of goods and services, f.o.b. (US\$) & 28.9 & 31.2 & 1.3 & -11.7 & 16.5 \\
\hline Terms of trade & -9.5 & 0.8 & 12.1 & 0.7 & 7.9 \\
\hline Nominal effective exchange rate (depreciation -$)^{2}$ & -0.9 & -10.0 & -7.8 & -9.3 & $\ldots$ \\
\hline Real effective exchange rate (depreciation -$)^{2}$ & 3.3 & -5.4 & -3.0 & -2.6 & $\ldots$ \\
\hline Nominal exchange rate (pula per US\$, average) & 4.9 & 4.7 & 5.1 & 5.8 & $\ldots$ \\
\hline Nominal exchange rate (pula per US\$, end of period) & 4.4 & 4.3 & 5.5 & 6.0 & $\ldots$ \\
\hline \multicolumn{6}{|l|}{ Central government finance ${ }^{3}$} \\
\hline Total revenue and grants & 13.1 & 10.9 & 24.0 & 22.5 & 8.9 \\
\hline Total expenditure and net lending & 3.6 & 6.8 & 1.4 & 11.7 & 21.7 \\
\hline \multicolumn{6}{|l|}{ Money and banking } \\
\hline Net foreign assets & -19.7 & 1.3 & 42.1 & 36.0 & 30.0 \\
\hline Net domestic assets & -53.8 & -22.3 & 140.2 & 81.5 & 36.5 \\
\hline Money and quasi money (M2) & 17.6 & 13.9 & 10.6 & 67.4 & 23.6 \\
\hline Velocity (GDP relative to $\mathrm{M} 2$ ) & 3.5 & 3.5 & 3.6 & 2.5 & 2.3 \\
\hline Velocity (non-mineral GDP relative to M2) & 2.2 & 2.2 & 2.2 & 1.5 & 1.4 \\
\hline Credit to the private sector & 11.9 & 24.1 & 8.8 & 20.7 & 22.0 \\
\hline Bank of Botswana lending rate (percent) ${ }^{4}$ & 14.3 & 14.3 & 14.5 & 15.0 & $\ldots$ \\
\hline Bank of Botswana certificate rate ( 3 months, percent $)^{4}$ & 12.7 & 12.5 & 12.3 & 12.7 & $\ldots$ \\
\hline \multirow[t]{2}{*}{ Prime lending rate (percent) ${ }^{4}$} & 15.8 & 15.8 & 16.0 & 16.5 & $\ldots$ \\
\hline & \multicolumn{5}{|c|}{ (Percent of GDP, unless otherwise indicated) } \\
\hline \multicolumn{6}{|l|}{ Investment and savings ${ }^{1,5}$} \\
\hline Gross investment & 41.8 & 35.8 & 26.2 & 27.4 & 31.6 \\
\hline Public & 9.8 & 7.8 & 6.7 & 6.8 & 8.6 \\
\hline Private & 32.0 & 28.0 & 19.5 & 20.5 & 23.0 \\
\hline Gross domestic savings & 51.3 & 48.0 & 44.0 & 46.7 & 45.7 \\
\hline Public & 8.2 & 10.4 & 15.6 & 17.2 & 16.1 \\
\hline Private & 43.1 & 37.6 & 28.4 & 29.4 & 29.7 \\
\hline Saving-investment balance & 9.5 & 12.2 & 17.8 & 19.3 & 14.2 \\
\hline \multicolumn{6}{|l|}{ Central government finance ${ }^{3}$} \\
\hline Total revenue and grants & 38.8 & 37.5 & 40.3 & 42.5 & 41.1 \\
\hline Total expenditure and net lending & 39.0 & 36.3 & 31.9 & 30.7 & 33.1 \\
\hline Overall balance (deficit -) & -0.2 & 1.2 & 8.4 & 11.8 & 8.0 \\
\hline \multicolumn{6}{|l|}{ External sector } \\
\hline Current account balance & 5.6 & 2.9 & 14.4 & 19.3 & 20.4 \\
\hline Balance of payments & 1.9 & -0.6 & 13.2 & 16.6 & 17.2 \\
\hline External public debt ${ }^{6}$ & 5.4 & 4.3 & 4.1 & 3.5 & 2.7 \\
\hline \multirow[t]{2}{*}{ External public debt (percent of total exports) } & 12.1 & 9.5 & 8.1 & 6.9 & 5.1 \\
\hline & \multicolumn{5}{|c|}{ (US $\$$ millions, unless otherwise indicated) } \\
\hline Change in reserves (increase -) & -162 & 58 & $-1,390$ & $-1,764$ & $-1,953$ \\
\hline Gross official reserves (end of period) & 5,339 & 5,653 & 6,278 & 7,954 & 9,907 \\
\hline (Months of imports of goods and services) $^{7}$ & 17.5 & 18.3 & 23.0 & 25.0 & 24.4 \\
\hline
\end{tabular}

${ }^{1}$ Year beginning July 1. Based on data included in February 2007 CSO Stats Brief, to reflect pending revision of July 2007 Stats Brief.

${ }^{2}$ Annual average. Zimbabwe is not included as a trading partner, as its hyperinflation distorts the calculation for Botswana.

${ }^{3}$ Year beginning April 1.

${ }^{4}$ End of period.

${ }^{5}$ Based on balance of payments data. The domestic savings-investment balance in the national accounts differs from the external current account

balance due to differences in timing and methodology.

${ }^{6}$ Medium- and long-term public and publicly guaranteed debt.

${ }^{7}$ Based on imports of goods and services for the following year. 
Table 3. Sectoral GDP and Savings-Investment Balances, 2002/03-2010/11 ${ }^{1}$

\begin{tabular}{|c|c|c|c|c|c|c|c|c|c|}
\hline & $2002 / 03$ & $2003 / 04$ & $2004 / 05$ & $2005 / 06$ & $2006 / 07$ & $2007 / 08$ & $2008 / 09$ & $2009 / 10$ & 2010/11 \\
\hline & \multicolumn{9}{|c|}{ (Millions of pula) } \\
\hline Consumption & 20,254 & 20,734 & 25,802 & 31,978 & 35,463 & 40,337 & 45,868 & 50,939 & 56,780 \\
\hline Public & 8,967 & 9,286 & 10,811 & 11,786 & 12,419 & 13,977 & 15,621 & 17,346 & 19,014 \\
\hline Private & 11,287 & 11,448 & 14,991 & 20,192 & 23,044 & 26,360 & 30,248 & 33,592 & 37,766 \\
\hline Gross investment & 14,799 & 17,792 & 17,789 & 14,962 & 18,196 & 23,489 & 29,233 & 32,273 & 36,677 \\
\hline Public & 4,214 & 4,170 & 3,878 & 3,837 & 4,539 & 6,422 & 7,434 & 8,483 & 9,639 \\
\hline Private (including changes in stocks) & 10,585 & 13,622 & 13,910 & 11,125 & 13,657 & 17,068 & 21,798 & 23,791 & 27,039 \\
\hline Net exports of goods and services ${ }^{2}$ & 4,345 & 4,048 & 6,030 & 10,198 & 12,842 & 10,522 & 7,652 & 6,825 & 6,128 \\
\hline Exports of goods and services & 18,053 & 19,505 & 23,994 & 29,107 & 34,206 & 37,751 & 39,639 & 41,491 & 43,716 \\
\hline Imports of goods and services & $-13,708$ & $-15,458$ & $-17,963$ & $-18,909$ & $-21,364$ & $-27,229$ & $-31,988$ & $-34,666$ & $-37,588$ \\
\hline Gross domestic savings & 19,144 & 21,839 & 23,819 & 25,160 & 31,038 & 34,012 & 36,885 & 39,099 & 42,806 \\
\hline Public & 2,869 & 3,495 & 5,171 & 8,914 & 11,456 & 11,962 & 12,307 & 12,541 & 12,718 \\
\hline Private & 16,275 & 18,344 & 18,648 & 16,246 & 19,582 & 22,050 & 24,578 & 26,558 & 30,088 \\
\hline \multirow[t]{2}{*}{ GDP at market prices } & 39,398 & 42,573 & 49,621 & 57,137 & 66,501 & 74,349 & 82,753 & 90,038 & 99,586 \\
\hline & \multicolumn{9}{|c|}{ (Percent of GDP) } \\
\hline Consumption & 51.4 & 48.7 & 52.0 & 56.0 & 53.3 & 54.3 & 55.4 & 56.6 & 57.0 \\
\hline Public & 22.8 & 21.8 & 21.8 & 20.6 & 18.7 & 18.8 & 18.9 & 19.3 & 19.1 \\
\hline Private & 28.6 & 26.9 & 30.2 & 35.3 & 34.7 & 35.5 & 36.6 & 37.3 & 37.9 \\
\hline Gross investment & 37.6 & 41.8 & 35.8 & 26.2 & 27.4 & 31.6 & 35.3 & 35.8 & 36.8 \\
\hline Public & 10.7 & 9.8 & 7.8 & 6.7 & 6.8 & 8.6 & 9.0 & 9.4 & 9.7 \\
\hline Private (including changes in stock) & 26.9 & 32.0 & 28.0 & 19.5 & 20.5 & 23.0 & 26.3 & 26.4 & 27.2 \\
\hline Net exports of goods and services ${ }^{2}$ & 11.0 & 9.5 & 12.2 & 17.8 & 19.3 & 14.2 & 9.2 & 7.6 & 6.2 \\
\hline Exports of goods and services & 45.8 & 45.8 & 48.4 & 50.9 & 51.4 & 50.8 & 47.9 & 46.1 & 43.9 \\
\hline Imports of goods and services & -34.8 & -36.3 & -36.2 & -33.1 & -32.1 & -36.6 & -38.7 & -38.5 & -37.7 \\
\hline Gross domestic savings & 48.6 & 51.3 & 48.0 & 44.0 & 46.7 & 45.7 & 44.6 & 43.4 & 43.0 \\
\hline Public & 7.3 & 8.2 & 10.4 & 15.6 & 17.2 & 16.1 & 14.9 & 13.9 & 12.8 \\
\hline \multirow[t]{2}{*}{ Private } & 41.3 & 43.1 & 37.6 & 28.4 & 29.4 & 29.7 & 29.7 & 29.5 & 30.2 \\
\hline & \multicolumn{9}{|c|}{ (Annual percentage change, unless otherwise indicated) } \\
\hline Real GDP & 9.6 & 3.1 & 9.2 & -0.8 & 5.8 & 4.3 & 6.0 & 3.8 & 5.5 \\
\hline Of which: non-mineral real GDP & 8.8 & 5.0 & 3.3 & 1.8 & 5.8 & 10.4 & 8.6 & 7.6 & 7.3 \\
\hline Nominal GDP (billions of pula) & 39.4 & 42.6 & 49.6 & 57.1 & 66.5 & 74.3 & 82.8 & 90.0 & 99.6 \\
\hline Mineral & 14.7 & 15.1 & 19.2 & 22.2 & 26.9 & 28.7 & 29.0 & 28.7 & 28.5 \\
\hline Non-mineral ${ }^{3}$ & 24.7 & 27.5 & 30.4 & 35.0 & 39.6 & 45.6 & 53.8 & 61.3 & 71.1 \\
\hline Consumer prices (end of period) ${ }^{4}$ & 10.6 & 6.4 & 7.9 & 11.3 & 8.5 & 7.4 & 6.5 & 5.8 & 5.3 \\
\hline
\end{tabular}

${ }^{1}$ National accounts year beginning July 1. Based on data included in February 2007 CSO Stats Brief, to reflect pending revision of July 2007 Stats Brief.

${ }^{2}$ Based on balance of payments data. The domestic savings-investment balance in the national accounts differs from the external current account balance due to differences in timing and methodology.

${ }^{3}$ Stronger growth in non-mineral real GDP over the medium-term largely reflects significant investment in electricity generation, including the Morupule Power Station and the Mmamabula Energy Project.

${ }^{4}$ Calendar year. 
Table 4a. Monetary Survey, 2003-2007 ${ }^{1}$

\begin{tabular}{|c|c|c|c|c|c|}
\hline & 2003 & 2004 & 2005 & 2006 & $\begin{array}{c}2007 \\
\text { Proj. } \\
\end{array}$ \\
\hline & \multicolumn{5}{|c|}{ (Millions of pula, end of period) } \\
\hline Net foreign assets & 24,954 & 25,269 & 35,903 & 48,812 & 63,444 \\
\hline Bank of Botswana & 23,513 & 24,001 & 34,372 & 47,720 & 61,399 \\
\hline Assets & 23,578 & 24,106 & 34,491 & 47,839 & 61,533 \\
\hline Liabilities & 64 & 108 & 118 & 123 & 140 \\
\hline Commercial banks & 1,441 & 1,268 & 1,531 & 1,093 & 2,045 \\
\hline Assets & 1,938 & 1,779 & 2,993 & 2,863 & 4,062 \\
\hline Liabilities & 496 & 511 & 1,462 & 1,771 & 2,017 \\
\hline Net other foreign assets & -1 & 3 & -1 & 4 & 6 \\
\hline Net domestic assets & $-7,152$ & $-5,560$ & $-13,356$ & $-24,245$ & $-33,089$ \\
\hline Net domestic credit & $-2,630$ & -452 & $-3,410$ & $-9,878$ & $-17,565$ \\
\hline Net claims on the government & $-10,372$ & $-10,045$ & $-13,703$ & $-22,246$ & $-32,600$ \\
\hline Bank of Botswana & $-10,804$ & $-9,541$ & $-13,223$ & $-21,236$ & $-31,450$ \\
\hline Commercial banks & 466 & 31 & 62 & 12 & 14 \\
\hline Other financial institutions & -34 & -535 & -542 & $-1,022$ & $-1,164$ \\
\hline Claims on nongovernment & 7,742 & 9,593 & 10,293 & 12,368 & 15,035 \\
\hline Claims on parastatals & 315 & 372 & 262 & 261 & 264 \\
\hline Claims on the private sector & 7,428 & 9,221 & 10,030 & 12,108 & 14,771 \\
\hline Other items (net) & $-4,522$ & $-5,108$ & $-9,946$ & $-14,367$ & $-15,523$ \\
\hline Capital & $-1,530$ & $-1,976$ & $-2,197$ & $-2,716$ & $-3,094$ \\
\hline Bank of Botswana & -54 & -54 & -59 & -65 & -74 \\
\hline Commercial banks & $-1,476$ & $-1,922$ & $-2,137$ & $-2,651$ & $-3,020$ \\
\hline Reserves & $-1,600$ & $-1,600$ & $-1,600$ & $-1,600$ & $-1,600$ \\
\hline Bank of Botswana & $-1,600$ & $-1,600$ & $-1,600$ & $-1,600$ & $-1,600$ \\
\hline Commercial banks & 0 & 0 & 0 & 0 & 0 \\
\hline Valuation adjustment $^{2}$ & $-1,105$ & $-1,401$ & $-5,543$ & $-8,692$ & $-9,614$ \\
\hline Net unclassified assets & -288 & -131 & -606 & $-1,359$ & $-1,215$ \\
\hline Money plus quasi-money (M2) & 11,645 & 13,262 & 14,674 & 24,568 & 30,356 \\
\hline Money & 2,882 & 4,225 & 3,998 & 5,157 & 6,372 \\
\hline Currency & 533 & 632 & 625 & 753 & 930 \\
\hline Current deposits & 2,350 & 3,592 & 3,372 & 4,404 & 5,441 \\
\hline Quasi money & 8,763 & 9,037 & 10,676 & 19,411 & 23,984 \\
\hline Other monetary liabilities ${ }^{3}$ & 6,157 & 6,447 & 7,873 & 0 & 0 \\
\hline Broad money (M3) & 17,802 & 19,708 & 22,547 & 24,568 & 30,356 \\
\hline & \multicolumn{5}{|c|}{ (12-month percentage change) } \\
\hline Net foreign assets & -19.7 & 1.3 & 42.1 & 36.0 & 30.0 \\
\hline Bank of Botswana & -20.8 & 2.1 & 43.2 & 38.8 & 28.7 \\
\hline Commercial banks & 5.5 & -12.0 & 20.8 & -28.6 & 87.1 \\
\hline Net domestic assets & -53.8 & -22.3 & 140.2 & 81.5 & 36.5 \\
\hline Net domestic credit & -73.7 & -82.8 & 654.1 & 189.6 & 77.8 \\
\hline Net claims on the government & -39.2 & -3.2 & 36.4 & 62.3 & 46.5 \\
\hline of which: Bank of Botswana & -36.4 & -11.7 & 38.6 & 60.6 & 48.1 \\
\hline Claims on nongovernment & 9.8 & 23.9 & 7.3 & 20.2 & 21.6 \\
\hline Claims on parastatals & -24.9 & 18.1 & -29.4 & -0.6 & 1.2 \\
\hline Claims on the private sector & 11.9 & 24.1 & 8.8 & 20.7 & 22.0 \\
\hline Other items (net) & -17.5 & 13.0 & 94.7 & 44.5 & 8.0 \\
\hline Money plus quasi-money (M2) & 17.6 & 13.9 & 10.6 & 67.4 & 23.6 \\
\hline Broad money (M3) & 14.3 & 10.7 & 14.4 & 9.0 & 23.6 \\
\hline \multicolumn{6}{|l|}{ Memorandum items: } \\
\hline Nominal GDP (calendar year) & 40,986 & 46,097 & 53,379 & 61,819 & 70,425 \\
\hline Nominal non-mineral GDP (calendar year) & 26,094 & 28,946 & 32,679 & 37,260 & 42,588 \\
\hline Velocity (GDP relative to broad money, M2) & 3.5 & 3.5 & 3.6 & 2.5 & 2.3 \\
\hline Velocity (non-mineral GDP relative to broad money, M2) & 2.2 & 2.2 & 2.2 & 1.5 & 1.4 \\
\hline Private sector credit to GDP & 18.1 & 20.0 & 18.8 & 19.6 & 21.0 \\
\hline Private sector credit to non-mineral GDP & 28.5 & 31.9 & 30.7 & 32.5 & 34.7 \\
\hline
\end{tabular}

Sources: Bank of Botswana; and IMF staff estimates and projections.

${ }^{1}$ This table represents a depository corporations survey and the data are for end of period.

${ }^{2}$ Valuation adjustment reflects gains and losses arising from the valuation of foreign exchange reserves.

${ }^{3}$ Other monetary liabilties include Bank of Botswana certificates which cannot be held by nonbank financial institutions since March 2006 
Table 4b. Bank of Botswana Accounts, 2003-2007

\begin{tabular}{|c|c|c|c|c|c|}
\hline & 2003 & 2004 & 2005 & 2006 & 2007 \\
\hline & & & & & Proj. \\
\hline & \multicolumn{5}{|c|}{ (Millions of pula, end of period) } \\
\hline Net foreign assets & 23,513 & 24,001 & 34,372 & 47,720 & 61,399 \\
\hline Of which: Pula Fund & 19,683 & 20,013 & 24,867 & 36,855 & 48,610 \\
\hline Net domestic assets & $-13,374$ & $-12,484$ & $-20,394$ & $-31,588$ & $-43,022$ \\
\hline Claims on the public sector, net & $-10,804$ & $-9,541$ & $-13,223$ & $-21,236$ & $-31,450$ \\
\hline Claims on commercial banks, net & 0 & 12 & 0 & 0 & 0 \\
\hline Claims on private sector, net & 0 & 39 & 45 & 57 & 66 \\
\hline Capital account & 2,759 & 3,055 & 7,203 & 10,357 & 11,288 \\
\hline Other items, net & 188 & 61 & -13 & -52 & -351 \\
\hline Reserve money & 3,982 & 5,070 & 6,104 & 16,131 & 18,377 \\
\hline Currency in circulation & 818 & 911 & 935 & 1,070 & 1,218 \\
\hline Bankers' deposits & 3,104 & 3,555 & 5,003 & 15,045 & 17,138 \\
\hline Of which: BoBC & 2,583 & 3,202 & 4,543 & 14,003 & 15,425 \\
\hline Demand deposits & 60 & 603 & 166 & 17 & 20 \\
\hline Other monetary liabilties & 6,157 & 6,447 & 7,873 & 0 & 0 \\
\hline \multirow[t]{2}{*}{ Of which: BoBC } & 6,157 & 6,447 & 7,873 & 0 & 0 \\
\hline & \multicolumn{5}{|c|}{ (12-month percentage change) } \\
\hline Net foreign assets & -20.8 & 2.1 & 43.2 & 38.8 & 28.7 \\
\hline Net domestic assets & -36.1 & -6.7 & 63.4 & 54.9 & 36.2 \\
\hline Claims on the public sector, net & -36.4 & -11.7 & 38.6 & 60.6 & 48.1 \\
\hline Claims on commercial banks, net & 0.0 & 0.0 & 0.0 & 0.0 & 0.0 \\
\hline Claims on private sector, net & -100.0 & 0.0 & 16.3 & 27.0 & 16.3 \\
\hline Other items, net & 36.4 & -67.8 & -121.5 & 301.5 & 570.3 \\
\hline Reserve money & 28.5 & 27.3 & 20.4 & 164.3 & 13.9 \\
\hline Currency in circulation & 7.8 & 11.4 & 2.7 & 14.4 & 13.9 \\
\hline Bankers' deposits & 36.0 & 14.5 & 40.7 & 200.7 & 13.9 \\
\hline Demand deposits & 4.5 & 907.8 & -72.4 & -89.7 & 17.6 \\
\hline Other monetary liabilities & 8.5 & 4.7 & 22.1 & 0.0 & 0.0 \\
\hline
\end{tabular}

Sources: Bank of Botswana; and IMF staff estimates and projections. 
Table 4c. Commercial Bank Accounts, 2003-2007

\begin{tabular}{|c|c|c|c|c|c|}
\hline & 2003 & 2004 & 2005 & 2006 & $\begin{array}{l}2007 \\
\text { Proj. }\end{array}$ \\
\hline & \multicolumn{5}{|c|}{ (Millions of pula, end of period) } \\
\hline Net foreign assets & 1,441 & 1,268 & 1,531 & 1,093 & 2,045 \\
\hline Net domestic assets & 9,611 & 10,758 & 12,351 & 22,705 & 27,360 \\
\hline Reserves & 3,168 & 3,960 & 5,617 & 15,510 & 17,138 \\
\hline Assets & 3,170 & 3,964 & 5,723 & 15,560 & 17,193 \\
\hline Of which: cash & 285 & 278 & 310 & 317 & 288 \\
\hline Liabilities to Bank of Botswana & 1 & 4 & 105 & 50 & 55 \\
\hline Net domestic credit & 6,443 & 6,798 & 6,734 & 7,195 & 10,222 \\
\hline Claims on the public sector, net & 780 & 403 & 325 & 273 & -887 \\
\hline Of which: central government, net & 466 & 31 & 62 & 12 & 0 \\
\hline Claims on other financial corporations, net & -34 & -535 & -542 & $-1,022$ & $-1,164$ \\
\hline Claims on private sector, net & 7,428 & 9,182 & 9,986 & 12,051 & 14,705 \\
\hline Other items, net & -255 & -330 & -897 & $-1,456$ & 588 \\
\hline Capital & 1,476 & 1,922 & 2,137 & 2,651 & 3,020 \\
\hline Liquid liabilities & 11,053 & 12,026 & 13,882 & 23,797 & 29,405 \\
\hline Demand deposits & 2,290 & 2,989 & 3,206 & 4,387 & 5,421 \\
\hline \multirow[t]{2}{*}{ Other deposits } & 8,763 & 9,037 & 10,676 & 19,411 & 23,984 \\
\hline & \multicolumn{5}{|c|}{ (12-month percentage change) } \\
\hline Net foreign assets & 5.5 & -12.0 & 20.8 & -28.6 & 87.1 \\
\hline Net domestic assets & 20.1 & 11.9 & 14.8 & 83.8 & 20.5 \\
\hline Reserves & 28.6 & 25.0 & 41.8 & 176.1 & 10.5 \\
\hline Assets & 25.4 & 25.1 & 44.4 & 171.9 & 10.5 \\
\hline Of which: cash & -1.4 & -2.4 & 11.3 & 2.2 & -9.1 \\
\hline Liabilities to Bank of Botswana & -97.9 & 217.5 & 2415.4 & -52.8 & 10.5 \\
\hline Net domestic credit & 16.2 & 5.5 & -0.9 & 6.8 & 42.1 \\
\hline Claims on the public sector, net & 105.3 & -48.4 & -19.4 & -16.0 & -425.1 \\
\hline Of which: central government, net & -1297.3 & -93.3 & 100.4 & -80.5 & 0.0 \\
\hline Claims on other financial corporations, net & -16.6 & 1460.7 & 1.3 & 88.5 & 13.9 \\
\hline Claims on private sector, net & 12.4 & 23.6 & 8.7 & 20.7 & 22.0 \\
\hline Other items, net & 36.9 & 29.4 & 171.8 & 62.2 & -140.4 \\
\hline Capital & 21.2 & 30.2 & 11.2 & 24.0 & 13.9 \\
\hline Liquid liabilities & 17.9 & 8.8 & 15.4 & 71.4 & 23.6 \\
\hline Demand deposits & 11.5 & 30.5 & 7.3 & 36.8 & 23.6 \\
\hline Other deposits & 19.7 & 3.1 & 18.1 & 81.8 & 23.6 \\
\hline
\end{tabular}


Table 5a. Central Government Operations, 2003/04-2007/08 ${ }^{1}$

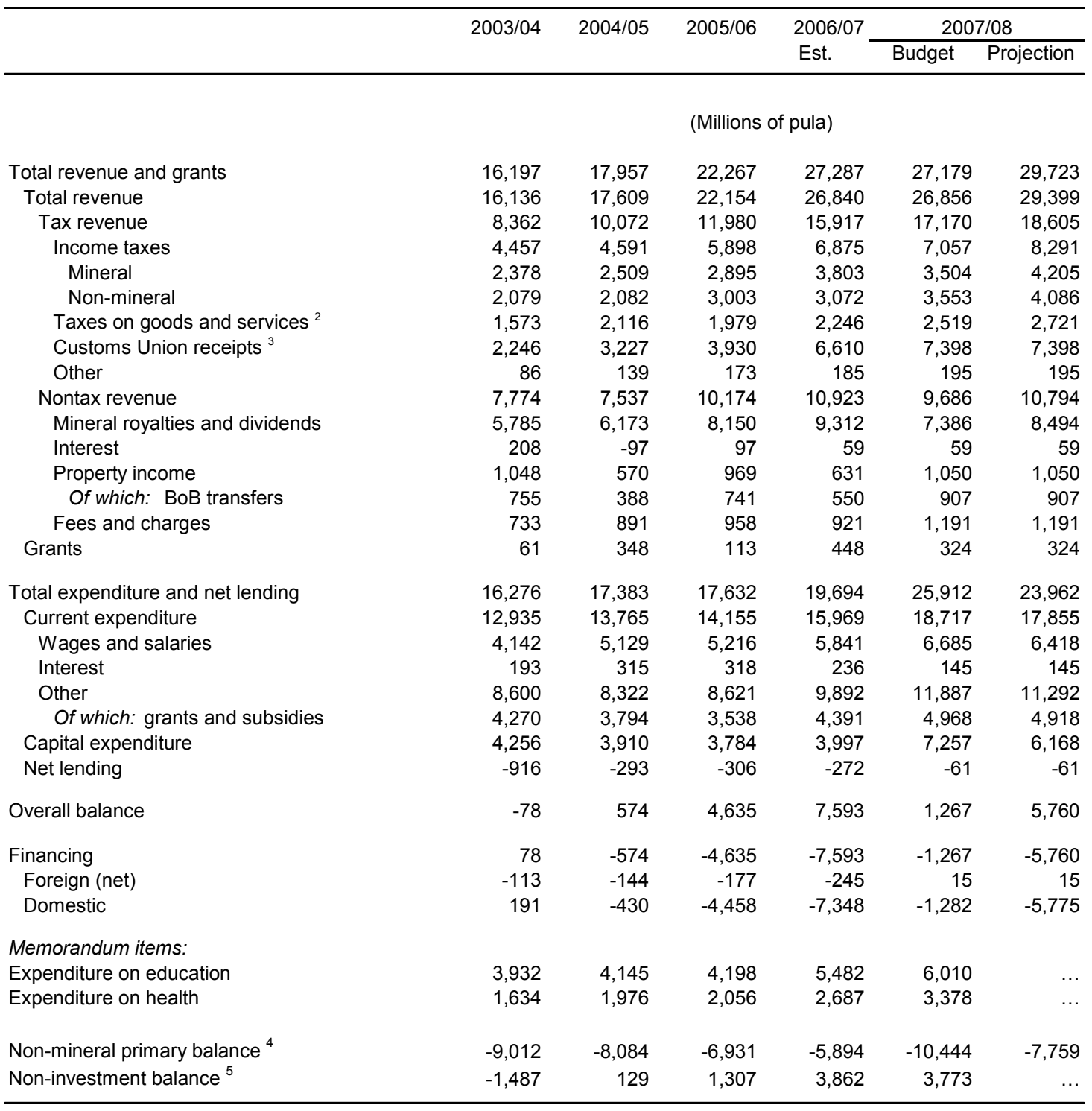

Sources: Ministry of Finance and Development Planning; and IMF staff estimates and projections.

${ }^{1}$ Fiscal year begins on April 1.

${ }^{2}$ Refers to sales tax and VAT.

${ }^{3} \mathrm{SACU}$ receipts consist of external trade and excises on imported goods as well as a development component derived from excises.

${ }^{4}$ The non-mineral primary balance is computed as the difference between non-mineral revenue and expenditure (excluding interest payments and receipts, which are roughly proxied by BoB transfers and interest).

${ }^{5}$ This balance is defined as the difference between non-mineral revenues and current spending (excluding interest receipts and payments and health and education spending, which the authorities regard as investment in human capital). 
Table 5b. Central Government Operations, 2003/04-2007/08 ${ }^{1}$

\begin{tabular}{|c|c|c|c|c|c|c|}
\hline & $2003 / 04$ & $2004 / 05$ & $2005 / 06$ & 2006/07 & 2007 & $7 / 08$ \\
\hline & & & & Est. & Budget & Projection \\
\hline & & & (Percent & f GDP) & & \\
\hline Total revenue and grants & 38.8 & 37.5 & 40.3 & 42.5 & 37.5 & 41.1 \\
\hline Total revenue & 38.6 & 36.8 & 40.1 & 41.8 & 37.1 & 40.6 \\
\hline Tax revenue & 20.0 & 21.0 & 21.7 & 24.8 & 23.7 & 25.7 \\
\hline Income taxes & 10.7 & 9.6 & 10.7 & 10.7 & 9.7 & 11.5 \\
\hline Mineral & 5.7 & 5.2 & 5.2 & 5.9 & 4.8 & 5.8 \\
\hline Non-mineral & 5.0 & 4.4 & 5.4 & 4.8 & 4.9 & 5.6 \\
\hline Taxes on goods and services ${ }^{2}$ & 3.8 & 4.4 & 3.6 & 3.5 & 3.5 & 3.8 \\
\hline Customs Union receipts ${ }^{3}$ & 5.4 & 6.7 & 7.1 & 10.3 & 10.2 & 10.2 \\
\hline Other & 0.2 & 0.3 & 0.3 & 0.3 & 0.3 & 0.3 \\
\hline Nontax revenue & 18.6 & 15.7 & 18.4 & 17.0 & 13.4 & 14.9 \\
\hline Mineral royalties and dividends & 13.8 & 12.9 & 14.7 & 14.5 & 10.2 & 11.7 \\
\hline Interest & 0.5 & -0.2 & 0.2 & 0.1 & 0.1 & 0.1 \\
\hline Property income & 2.5 & 1.2 & 1.8 & 1.0 & 1.5 & 1.5 \\
\hline Of which: BoB transfers & 1.8 & 0.8 & 1.3 & 0.9 & 1.3 & 1.3 \\
\hline Fees and charges & 1.8 & 1.9 & 1.7 & 1.4 & 1.6 & 1.6 \\
\hline Grants & 0.1 & 0.7 & 0.2 & 0.7 & 0.4 & 0.4 \\
\hline Total expenditure and net lending & 39.0 & 36.3 & 31.9 & 30.7 & 35.8 & 33.1 \\
\hline Current expenditure & 31.0 & 28.8 & 25.6 & 24.9 & 25.9 & 24.7 \\
\hline Wages and salaries & 9.9 & 10.7 & 9.4 & 9.1 & 9.2 & 8.9 \\
\hline Interest & 0.5 & 0.7 & 0.6 & 0.4 & 0.2 & 0.2 \\
\hline Other & 20.6 & 17.4 & 15.6 & 15.4 & 16.4 & 15.6 \\
\hline Of which: grants and subsidies & 10.2 & 7.9 & 6.4 & 6.8 & 6.9 & 6.8 \\
\hline Capital expenditure & 10.2 & 8.2 & 6.8 & 6.2 & 10.0 & 8.5 \\
\hline Net lending & -2.2 & -0.6 & -0.6 & -0.4 & -0.1 & -0.1 \\
\hline Overall balance & -0.2 & 1.2 & 8.4 & 11.8 & 1.8 & 8.0 \\
\hline Financing & 0.2 & -1.2 & -8.4 & -11.8 & -1.8 & -8.0 \\
\hline Foreign (net) & -0.3 & -0.3 & -0.3 & -0.4 & 0.0 & 0.0 \\
\hline Domestic & 0.5 & -0.9 & -8.1 & -11.5 & -1.8 & -8.0 \\
\hline Memorandum items: & & & & & & \\
\hline Expenditure on education & 9.4 & 8.7 & 7.6 & 8.5 & 8.3 & $\ldots$ \\
\hline Expenditure on health & 3.9 & 4.1 & 3.7 & 4.2 & 4.7 & $\ldots$ \\
\hline $\begin{array}{l}\text { Non-mineral primary balance }{ }^{4} \\
\text { (percent of non-mineral GDP) }\end{array}$ & -33.6 & -27.2 & -20.5 & -15.3 & -23.7 & -17.6 \\
\hline $\begin{array}{l}\text { Non-investment balance }{ }^{5} \\
\text { (percent of non-mineral GDP) }\end{array}$ & -5.5 & 0.4 & 3.9 & 10.1 & 8.6 & $\cdots$ \\
\hline GDP (fiscal year; millions of pula) & $41,779.3$ & $47,858.9$ & $55,258.3$ & $64,160.3$ & $72,386.7$ & $72,386.7$ \\
\hline
\end{tabular}

Sources: Ministry of Finance and Development Planning; and IMF staff estimates and projections.

${ }^{1}$ Fiscal year begins on April 1.

${ }^{2}$ Refers to sales tax and VAT.

${ }^{3}$ SACU receipts consist of external trade and excises on imported goods as well as a development component derived from excises.

${ }^{4}$ The non-mineral primary balance is computed as the difference between non-mineral revenue and expenditure (excluding interest payments and receipts, which are roughly proxied by BoB transfers and interest).

${ }^{5}$ This balance is defined as the difference between non-mineral revenues and current spending (excluding interest receipts and payments and health and education spending, which the authorities regard as investment in human capital) and then divided by non-mineral GDP. 
Table 6. Balance of Payments, 2003-2007 ${ }^{1}$

\begin{tabular}{|c|c|c|c|c|c|}
\hline & 2003 & 2004 & 2005 & 2006 & 2007 \\
\hline & \multicolumn{4}{|c|}{ (US\$ millions, unless otherwise indicated) } & \\
\hline Current account balance & 464 & 288 & 1,517 & 2,051 & 2,312 \\
\hline Trade balance & 900 & 833 & 1,619 & 1,964 & 2,103 \\
\hline $\begin{array}{l}\text { Exports, f.o.b. } \\
\text { Of which: }\end{array}$ & 3,035 & 3,701 & 4,472 & 4,567 & 5,185 \\
\hline Diamonds & 2,374 & 2,802 & 3,355 & 3,390 & 3,326 \\
\hline Other raw materials & 187 & 215 & 520 & 737 & 1,128 \\
\hline Other & 474 & 683 & 597 & 440 & 732 \\
\hline Imports, f.o.b & $-2,135$ & $-2,868$ & $-2,853$ & $-2,603$ & $-3,082$ \\
\hline Services & -9 & -44 & 33 & 105 & 97 \\
\hline Transportation & -180 & -208 & -258 & -228 & -246 \\
\hline Travel & 228 & 273 & 282 & 268 & 285 \\
\hline Other services & -57 & -109 & 8 & 65 & 58 \\
\hline Income & -718 & $-1,028$ & -820 & -666 & -758 \\
\hline Current transfers & 291 & 527 & 685 & 647 & 870 \\
\hline Capital and financial account & -358 & -300 & -27 & -270 & -359 \\
\hline Capital account & 23 & 32 & 32 & 22 & 20 \\
\hline Financial account & -380 & -332 & -58 & -291 & -379 \\
\hline Direct investment & 213 & 430 & 225 & 253 & 286 \\
\hline Portfolio investment & -522 & -468 & -392 & -505 & -544 \\
\hline Other investment & -70 & -295 & 109 & -39 & -122 \\
\hline \multicolumn{6}{|l|}{ Of which: } \\
\hline Net government long-term borrowing & -22 & -25 & -10 & -33 & 10 \\
\hline Other net private long-term borrowing & 3 & 4 & 5 & 3 & 28 \\
\hline Short-term borrowing & 93 & 62 & 60 & 53 & 55 \\
\hline Reserve assets (increase -) & -162 & 58 & $-1,390$ & $-1,764$ & $-1,953$ \\
\hline Net errors and omissions & 55 & -46 & -100 & -18 & 0 \\
\hline Memorandum items: & \multicolumn{4}{|c|}{ (Percent of GDP, unless otherwise indicated) } & \\
\hline Balance of payments & 1.9 & -0.6 & 13.2 & 16.6 & 17.2 \\
\hline Current account & 5.6 & 2.9 & 14.4 & 19.3 & 20.4 \\
\hline Trade balance & 10.8 & 8.5 & 15.4 & 18.5 & 18.5 \\
\hline Exports of goods & 36.5 & 37.6 & 42.4 & 43.0 & 45.7 \\
\hline Of which: diamonds & 28.6 & 28.5 & 31.8 & 31.9 & 29.3 \\
\hline Imports of goods & -25.7 & -29.2 & -27.0 & -24.5 & -27.1 \\
\hline Services balance & -0.1 & -0.4 & 0.3 & 1.0 & 0.9 \\
\hline Income and transfers balance & -5.1 & -5.1 & -1.3 & -0.2 & 1.0 \\
\hline Financial account & -4.6 & -3.4 & -0.6 & -2.7 & -3.3 \\
\hline \multirow[t]{2}{*}{ Direct investment } & 2.6 & 4.4 & 2.1 & 2.4 & 2.5 \\
\hline & \multicolumn{4}{|c|}{ (Annual percentage change, unless otherwise indicated) } & \\
\hline Export volumes & 13.7 & 7.2 & 2.7 & 1.6 & 3.9 \\
\hline Import volumes & 19.2 & 21.4 & -10.1 & -3.6 & 15.0 \\
\hline Terms of trade & -9.5 & 0.8 & 12.1 & 0.7 & 7.9 \\
\hline End-of-year reserves (US\$ millions) ${ }^{2}$ & 5,339 & 5,653 & 6,278 & 7,954 & 9,907 \\
\hline (Months of imports of goods and services) ${ }^{3}$ & 17.5 & 18.3 & 23.0 & 25.0 & 24.4 \\
\hline Pula Fund (US\$ millions) ${ }^{2}$ & 4,332 & 4,681 & 4,533 & 6,140 & $\ldots$ \\
\hline (Months of imports of goods and services) ${ }^{3}$ & 14.2 & 15.1 & 16.6 & 19.3 & $\ldots$ \\
\hline Other reserves (US\$ millions) ${ }^{2}$ & 1,006 & 972 & 1,745 & 1,814 & $\ldots$ \\
\hline (Months of imports of goods and services) $^{3}$ & 3.3 & 3.1 & 6.4 & 5.7 & $\ldots$ \\
\hline \multicolumn{6}{|l|}{ Exchange rate } \\
\hline Dollar/pula (period average) & 0.203 & 0.213 & 0.198 & 0.172 & $\ldots$ \\
\hline Dollar/pula (end of period ) & 0.225 & 0.234 & 0.181 & 0.166 & $\ldots$ \\
\hline
\end{tabular}

Sources: Botswana authorities; and IMF staff estimates and projections.

1 Based on pula-denominated estimates converted at period-average exchange rate.

${ }^{2}$ Includes valuation adjustment.

${ }^{3}$ Based on imports of goods and services for the following year. 
Table 7. Banking System Prudential Indicators, 2003-2006

\begin{tabular}{|c|c|c|c|c|}
\hline & 2003 & 2004 & 2005 & 2006 \\
\hline & \multicolumn{4}{|c|}{ (Percent, unless otherwise indicated) } \\
\hline \multicolumn{5}{|l|}{ Capital adequacy } \\
\hline Regulatory capital (millions of pula) & $1,450.9$ & $1,404.1$ & $1,568.6$ & $1,743.2$ \\
\hline Tier 1 capital (millions of pula) & 858.4 & 915.8 & 961.4 & $1,071.3$ \\
\hline Regulatory Tier I capital to risk-weighted assets & 11.9 & 11.0 & 10.6 & 10.3 \\
\hline Capital-to-assets ${ }^{1}$ & 11.2 & 9.5 & 8.8 & 6.0 \\
\hline \multicolumn{5}{|l|}{ Asset composition and quality } \\
\hline Loans-to-assets & 56.2 & 57.0 & 51.2 & 36.9 \\
\hline Nonperforming loans (NPLs)-to-gross loans & 0.9 & 0.8 & 0.9 & 0.9 \\
\hline Compromised assets-to-gross loans ${ }^{2}$ & 2.8 & 2.7 & 2.6 & 3.7 \\
\hline NPLs net of specific provisions-to-tier I capital ${ }^{2}$ & 0.0 & 0.0 & 0.0 & 0.0 \\
\hline \multicolumn{5}{|l|}{ Profitability } \\
\hline Return on average assets & 5.0 & 5.0 & 5.5 & 6.1 \\
\hline Return on average equity & 46.8 & 50.7 & 62.5 & 89.2 \\
\hline \multicolumn{5}{|l|}{ Liquidity } \\
\hline Liquid assets to total assets & 19.7 & 21.8 & 26.1 & 47.1 \\
\hline Liquid assets to short-term liabilities & 24.1 & 27.4 & 35.5 & 60.5 \\
\hline Foreign currency denominated loans to total loans & 7.4 & 11.0 & 7.7 & 12.1 \\
\hline Foreign currency denominated liabilities to total liabilities & 21.3 & 18.4 & 22.5 & 29.1 \\
\hline Loans-to-deposits & 68.9 & 71.2 & 68.7 & 46.7 \\
\hline \multicolumn{5}{|l|}{ Sensitivity to market risk } \\
\hline Net open foreign exchange (FX) position as percent of regulatory capital ${ }^{3}$ & -28.3 & -19.3 & 8.3 & -18.1 \\
\hline Contingent foreign exchange $(\mathrm{FX})$ assets-to-regulatory capital & 31.6 & 23.6 & 70.7 & 258.2 \\
\hline Contingent foreign exchange ( $F X)$ liabilities-to-regulatory capital & 55.5 & 44.7 & 52.4 & 88.4 \\
\hline
\end{tabular}

Source: Bank of Botswana and FSAP estimates.

${ }^{1}$ The drop in the capital -to-assets ratio is due to an increase in the holding of zero risk weighted assets (BoBCs) by the banks.

${ }^{2}$ NPLs are defined as credits with interest past due of 182 days or more; compromised assets are defined as credits with interest past due of 91 days or more.

${ }^{3}$ Foreign currency liabilities less foreign currency assets as a percent of regulatory capital. 
Table 8. Medium-Term Economic and Financial Indicators, 2007-2011

\begin{tabular}{|c|c|c|c|c|c|}
\hline & 2007 & 2008 & 2009 & 2010 & 2011 \\
\hline & \multicolumn{4}{|c|}{ (Annual percentage change, unless otherwise indicated) } & \\
\hline \multicolumn{6}{|l|}{ National income and prices } \\
\hline Real GDP ${ }^{1}$ & 4.3 & 6.0 & 3.8 & 5.5 & 6.9 \\
\hline Mineral & -4.3 & 1.9 & -2.7 & 2.0 & 4.0 \\
\hline Non-mineral & 10.4 & 8.6 & 7.6 & 7.3 & 8.3 \\
\hline Consumer prices (average) & 7.0 & 7.0 & 6.1 & 5.6 & 5.0 \\
\hline Consumer prices (end of period) & 7.4 & 6.5 & 5.8 & 5.3 & 5.0 \\
\hline Nominal GDP (billions of pula) ${ }^{1}$ & 74.3 & 82.8 & 90.0 & 99.6 & 111.7 \\
\hline Mineral & 28.7 & 29.0 & 28.7 & 28.5 & 31.3 \\
\hline Non-mineral $^{2}$ & 45.6 & 53.8 & 61.3 & 71.1 & 80.4 \\
\hline \multicolumn{6}{|l|}{ External sector } \\
\hline Exports of goods and services, f.o.b. (US\$) & 12.6 & 0.4 & 4.5 & -0.7 & 6.1 \\
\hline \multicolumn{6}{|l|}{ Of which: } \\
\hline Diamonds & -1.9 & -0.4 & 7.8 & -3.8 & 1.8 \\
\hline Other raw materials & 53.0 & -12.2 & -19.8 & -22.0 & 0.4 \\
\hline Other & 66.2 & 17.1 & 17.8 & 18.6 & 18.7 \\
\hline Imports of goods and services, f.o.b. (US\$) & 16.5 & 27.6 & 4.6 & 6.1 & 5.4 \\
\hline Terms of trade & 7.9 & -5.7 & -3.6 & -3.1 & -0.5 \\
\hline \multicolumn{6}{|l|}{ Central government finance ${ }^{3}$} \\
\hline Total revenue and grants & 8.9 & 8.2 & 6.7 & 6.8 & 8.2 \\
\hline Total expenditure and net lending & 21.7 & 12.9 & 10.7 & 11.1 & 11.8 \\
\hline \multicolumn{6}{|l|}{ Money and banking } \\
\hline Net foreign assets & 30.0 & 18.5 & 16.4 & 10.6 & 11.0 \\
\hline Net domestic assets & 36.5 & 24.9 & 21.6 & 11.2 & 10.6 \\
\hline Money and quasi money (M2) & 23.6 & 11.5 & 10.0 & 9.7 & 11.4 \\
\hline Velocity (GDP relative to M2) & 2.3 & 2.3 & 2.3 & 2.3 & 2.3 \\
\hline Velocity (non-mineral GDP relative to M2) & 1.4 & 1.5 & 1.5 & 1.6 & 1.7 \\
\hline \multirow[t]{2}{*}{ Credit to the private sector } & 22.0 & 11.5 & 10.0 & 9.7 & 11.4 \\
\hline & \multicolumn{5}{|c|}{ (Percent of GDP, unless otherwise indicated) } \\
\hline \multicolumn{6}{|l|}{ Investment and savings ${ }^{1,4}$} \\
\hline Gross investment & 31.6 & 35.3 & 35.8 & 36.8 & 34.1 \\
\hline Public & 8.6 & 9.0 & 9.4 & 9.7 & 9.6 \\
\hline Private & 23.0 & 26.3 & 26.4 & 27.2 & 24.4 \\
\hline Gross domestic savings & 45.7 & 44.6 & 43.4 & 43.0 & 42.8 \\
\hline Public & 16.1 & 14.9 & 13.9 & 12.8 & 11.6 \\
\hline Private & 29.7 & 29.7 & 29.5 & 30.2 & 31.1 \\
\hline Saving-investment balance & 14.2 & 9.2 & 7.6 & 6.2 & 8.7 \\
\hline \multicolumn{6}{|l|}{ Central government finance ${ }^{3}$} \\
\hline Total revenue and grants & 41.1 & 39.9 & 38.9 & 37.7 & 36.5 \\
\hline Total expenditure and net lending & 33.1 & 33.5 & 33.9 & 34.2 & 34.2 \\
\hline Overall balance (deficit -) & 8.0 & 6.4 & 5.0 & 3.5 & 2.3 \\
\hline \multicolumn{6}{|l|}{ External sector } \\
\hline Current account balance & 20.4 & 9.6 & 8.8 & 5.6 & 5.5 \\
\hline Balance of payments & 17.2 & 12.1 & 11.2 & 7.5 & 7.1 \\
\hline External public debt ${ }^{5}$ & 2.7 & 2.7 & 3.1 & 3.0 & 2.8 \\
\hline \multirow[t]{2}{*}{ External public debt in percent of total exports } & 5.1 & 5.5 & 6.5 & 6.7 & 6.5 \\
\hline & \multicolumn{5}{|c|}{ (US\$ millions, unless otherwise indicated) } \\
\hline Change in reserves (increase -) & $-1,953$ & $-1,507$ & $-1,484$ & $-1,071$ & $-1,093$ \\
\hline Gross official reserves (end of period) & 9,907 & 11,414 & 12,898 & 13,968 & 15,061 \\
\hline In months of imports of goods and services ${ }^{6}$ & 24.4 & 26.9 & 28.6 & 29.4 & 29.5 \\
\hline
\end{tabular}

${ }^{1}$ Year beginning July 1. Based on data included in February 2007 CSO Stats Brief, to reflect pending revision of July 2007 Stats Brief.

${ }^{2}$ Stronger growth in non-mineral real GDP over the medium-term largely reflects significant investment in electricity generation, including the Morupule Power Station and the Mmamabula Energy Project.

${ }^{3}$ Year beginning April 1.

${ }^{4}$ Based on balance of payments data. The domestic savings-investment balance in the national accounts differs from the external current account balance due to differences in timing and methodology.

${ }^{5}$ Medium- and long-term public and publicly guaranteed debt outstanding

${ }^{6}$ Based on imports of goods and services for the following year. 
Table 9a. Central Government Operations, 2007/08-2010/11 ${ }^{1}$

\begin{tabular}{|c|c|c|c|c|c|}
\hline & \multicolumn{2}{|c|}{$2007 / 08$} & \multirow[t]{2}{*}{$2008 / 09$} & \multirow[t]{2}{*}{$2009 / 10$} & \multirow[t]{2}{*}{$2010 / 11$} \\
\hline & Budget & Projection & & & \\
\hline & \multicolumn{5}{|c|}{ (Millions of pula) } \\
\hline Total revenue and grants & 27,179 & 29,723 & 32,173 & 34,323 & 36,653 \\
\hline Total revenue & 26,856 & 29,399 & 31,827 & 33,954 & 36,263 \\
\hline Tax revenue & 17,170 & 18,605 & 20,397 & 21,996 & 23,887 \\
\hline Income taxes & 7,057 & 8,291 & 9,156 & 9,954 & 10,873 \\
\hline Mineral & 3,504 & 4,205 & 4,361 & 4,446 & 4,512 \\
\hline Non-mineral & 3,553 & 4,086 & 4,795 & 5,508 & 6,360 \\
\hline Taxes on goods and services ${ }^{2}$ & 2,519 & 2,721 & 3,193 & 3,668 & 4,235 \\
\hline Customs Union receipts ${ }^{3}$ & 7,398 & 7,398 & 7,831 & 8,137 & 8,517 \\
\hline Other & 195 & 195 & 217 & 237 & 261 \\
\hline Nontax revenue & 9,686 & 10,794 & 11,430 & 11,958 & 12,376 \\
\hline Mineral royalties and dividends & 7,386 & 8,494 & 8,923 & 9,216 & 9,355 \\
\hline Interest & 59 & 59 & 65 & 72 & 79 \\
\hline Property income & 1,050 & 1,050 & 1,114 & 1,219 & 1,343 \\
\hline Of which: BoB transfers & 907 & 907 & 807 & 882 & 972 \\
\hline Fees and charges & 1,191 & 1,191 & 1,327 & 1,452 & 1,600 \\
\hline Grants & 324 & 324 & 346 & 369 & 391 \\
\hline Total expenditure and net lending & 25,912 & 23,962 & 27,044 & 29,942 & 33,259 \\
\hline Current expenditure & 18,717 & 17,855 & 19,929 & 21,826 & 23,980 \\
\hline Wages and salaries & 6,685 & 6,418 & 7,017 & 7,545 & 8,150 \\
\hline Interest & 145 & 145 & 146 & 147 & 148 \\
\hline Other & 11,887 & 11,292 & 12,766 & 14,134 & 15,682 \\
\hline Of which: grants and subsidies & 4,968 & 4,918 & 5,560 & 6,156 & 6,830 \\
\hline Capital expenditure & 7,257 & 6,168 & 7,182 & 8,190 & 9,360 \\
\hline Net lending & -61 & -61 & -68 & -74 & -82 \\
\hline Overall balance & 1,267 & 5,760 & 5,129 & 4,381 & 3,394 \\
\hline Financing & $-1,267$ & $-5,760$ & $-5,129$ & $-4,381$ & $-3,394$ \\
\hline Foreign (net) & 15 & 15 & 15 & 15 & 15 \\
\hline Domestic & $-1,282$ & $-5,775$ & $-5,144$ & $-4,396$ & $-3,409$ \\
\hline \multicolumn{6}{|l|}{ Memorandum items: } \\
\hline Expenditure on education & 6,010 & $\ldots$ & $\ldots$ & $\cdots$ & $\ldots$ \\
\hline Expenditure on health & 3,378 & $\ldots$ & $\ldots$ & $\cdots$ & $\cdots$ \\
\hline Non-mineral primary balance ${ }^{4}$ & $-10,444$ & $-7,759$ & $-8,882$ & $-10,087$ & $-11,376$ \\
\hline
\end{tabular}

Sources: Ministry of Finance and Development Planning; and IMF staff estimates and projections.

${ }^{1}$ Fiscal year begins on April 1.

${ }^{2}$ Refers to sales tax and VAT.

${ }^{3}$ SACU receipts consist of external trade and excises on imported goods as well as a development component derived from excises.

${ }^{4}$ The non-mineral primary balance is computed as the difference between non-mineral revenue and expenditure (excluding interest payments and receipts, which are roughly proxied by BoB transfers and interest). 
Table 9b. Central Government Operations, 2007/08-2010/11 ${ }^{1}$

\begin{tabular}{|c|c|c|c|c|c|}
\hline & \multicolumn{2}{|c|}{$2007 / 08$} & \multirow[t]{2}{*}{$2008 / 09$} & \multirow[t]{2}{*}{$2009 / 10$} & \multirow[t]{2}{*}{$2010 / 11$} \\
\hline & Budget & Projection & & & \\
\hline & \multicolumn{5}{|c|}{ (Percent of GDP) } \\
\hline Total revenue and grants & 37.5 & 41.1 & 39.9 & 38.9 & 37.7 \\
\hline Total revenue & 37.1 & 40.6 & 39.5 & 38.5 & 37.3 \\
\hline Tax revenue & 23.7 & 25.7 & 25.3 & 24.9 & 24.6 \\
\hline Income taxes & 9.7 & 11.5 & 11.4 & 11.3 & 11.2 \\
\hline Mineral & 4.8 & 5.8 & 5.4 & 5.0 & 4.6 \\
\hline Non-mineral & 4.9 & 5.6 & 5.9 & 6.2 & 6.5 \\
\hline Taxes on goods and services ${ }^{2}$ & 3.5 & 3.8 & 4.0 & 4.2 & 4.4 \\
\hline Customs Union receipts ${ }^{3}$ & 10.2 & 10.2 & 9.7 & 9.2 & 8.8 \\
\hline Other & 0.3 & 0.3 & 0.3 & 0.3 & 0.3 \\
\hline Nontax revenue & 13.4 & 14.9 & 14.2 & 13.6 & 12.7 \\
\hline Mineral royalties and dividends & 10.2 & 11.7 & 11.1 & 10.4 & 9.6 \\
\hline Interest & 0.1 & 0.1 & 0.1 & 0.1 & 0.1 \\
\hline Property income & 1.5 & 1.5 & 1.4 & 1.4 & 1.4 \\
\hline Of which: BoB transfers & 1.3 & 1.3 & 1.0 & 1.0 & 1.0 \\
\hline Fees and charges & 1.6 & 1.6 & 1.6 & 1.6 & 1.6 \\
\hline Grants & 0.4 & 0.4 & 0.4 & 0.4 & 0.4 \\
\hline Total expenditure and net lending & 35.8 & 33.1 & 33.5 & 33.9 & 34.2 \\
\hline Current expenditure & 25.9 & 24.7 & 24.7 & 24.7 & 24.7 \\
\hline Wages and salaries & 9.2 & 8.9 & 8.7 & 8.6 & 8.4 \\
\hline Interest & 0.2 & 0.2 & 0.2 & 0.2 & 0.2 \\
\hline Other & 16.4 & 15.6 & 15.8 & 16.0 & 16.1 \\
\hline Of which: grants and subsidies & 6.9 & 6.8 & 6.9 & 7.0 & 7.0 \\
\hline Capital expenditure & 10.0 & 8.5 & 8.9 & 9.3 & 9.6 \\
\hline Net lending & -0.1 & -0.1 & -0.1 & -0.1 & -0.1 \\
\hline Overall balance & 1.8 & 8.0 & 6.4 & 5.0 & 3.5 \\
\hline Financing & -1.8 & -8.0 & -6.4 & -5.0 & -3.5 \\
\hline Foreign (net) & 0.0 & 0.0 & 0.0 & 0.0 & 0.0 \\
\hline Domestic & -1.8 & -8.0 & -6.4 & -5.0 & -3.5 \\
\hline \multicolumn{6}{|l|}{ Memorandum items: } \\
\hline Expenditure on education & 8.3 & $\ldots$ & $\ldots$ & $\ldots$ & $\ldots$ \\
\hline Expenditure on health & 4.7 & $\ldots$ & $\ldots$ & $\cdots$ & $\cdots$ \\
\hline $\begin{array}{l}\text { Non-mineral primary balance }{ }^{4} \\
\text { (percent of non-mineral GDP) }\end{array}$ & -23.7 & -17.6 & -17.2 & -17.0 & -16.6 \\
\hline GDP (fiscal year; millions of pula) & $72,386.7$ & $72,386.7$ & $80,652.0$ & $88,216.4$ & $97,198.6$ \\
\hline
\end{tabular}

Sources: Ministry of Finance and Development Planning; and IMF staff estimates and projections.

${ }^{1}$ Fiscal year begins on April 1.

${ }^{2}$ Refers to sales tax and VAT.

${ }^{3}$ SACU receipts consist of external trade and excises on imported goods as well as a development component derived from excises.

${ }^{4}$ The non-mineral primary balance is computed as the difference between non-mineral revenue and expenditure (excluding interest payments and receipts, which are roughly proxied by BoB transfers and interest). 
Table 10. Balance of Payments, 2007-2011 ${ }^{1}$

\begin{tabular}{|c|c|c|c|c|c|}
\hline & 2007 & 2008 & 2009 & 2010 & 2011 \\
\hline & \multicolumn{5}{|c|}{ (US\$ millions, unless otherwise indicated) } \\
\hline Current account balance & 2,312 & 1,187 & 1,161 & 790 & 856 \\
\hline Trade balance & 2,103 & 1,102 & 1,157 & 791 & 871 \\
\hline $\begin{array}{l}\text { Exports, f.o.b. } \\
\text { Of which: }\end{array}$ & 5,185 & 5,160 & 5,375 & 5,251 & 5,540 \\
\hline Diamonds & 3,326 & 3,313 & 3,572 & 3,434 & 3,497 \\
\hline Other raw materials & 1,128 & 990 & 794 & 619 & 622 \\
\hline Other & 732 & 857 & 1,009 & 1,197 & 1,421 \\
\hline Imports, f.o.b & $-3,082$ & $-4,057$ & $-4,218$ & $-4,460$ & $-4,669$ \\
\hline Services & 97 & 68 & 57 & 68 & 80 \\
\hline Transportation & -246 & -282 & -308 & -341 & -374 \\
\hline Travel & 285 & 289 & 299 & 336 & 373 \\
\hline Other services & 58 & 60 & 66 & 73 & 81 \\
\hline Income & -758 & -886 & -950 & -965 & $-1,001$ \\
\hline Current transfers & 870 & 903 & 897 & 896 & 906 \\
\hline Capital and financial account & -359 & 319 & 323 & 281 & 237 \\
\hline Capital account & 20 & 20 & 19 & 19 & 18 \\
\hline Financial account & -379 & 300 & 304 & 262 & 219 \\
\hline Direct investment & 286 & 829 & 833 & 798 & 749 \\
\hline Portfolio investment & -544 & -564 & -571 & -581 & -569 \\
\hline Other investment & -122 & 35 & 42 & 45 & 39 \\
\hline \multicolumn{6}{|l|}{ Of which: } \\
\hline Net government long-term borrowing & 10 & 10 & 10 & 10 & 9 \\
\hline Other net private long-term borrowing & 28 & 106 & 120 & 136 & 154 \\
\hline Short-term borrowing & 55 & 56 & 57 & 54 & 51 \\
\hline Reserve assets (increase - ) & $-1,953$ & $-1,507$ & $-1,484$ & $-1,071$ & $-1,093$ \\
\hline Net errors and omissions & 0 & 0 & 0 & 0 & 0 \\
\hline Memorandum items: & \multicolumn{5}{|c|}{ (Percent of GDP, unless otherwise indicated) } \\
\hline Balance of payments & 17.2 & 12.1 & 11.2 & 7.5 & 7.1 \\
\hline Current account & 20.4 & 9.6 & 8.8 & 5.6 & 5.5 \\
\hline Trade balance & 18.5 & 8.9 & 8.7 & 5.6 & 5.6 \\
\hline Exports of goods & 45.7 & 41.5 & 40.5 & 37.0 & 35.9 \\
\hline Of which: diamonds & 29.3 & 26.7 & 26.9 & 24.2 & 22.7 \\
\hline Imports of goods & -27.1 & -32.6 & -31.8 & -31.4 & -30.3 \\
\hline Services balance & 0.9 & 0.5 & 0.4 & 0.5 & 0.5 \\
\hline Income and transfers balance & 1.0 & 0.1 & -0.4 & -0.5 & -0.6 \\
\hline Financial account & -3.3 & 2.4 & 2.3 & 1.8 & 1.4 \\
\hline \multirow[t]{2}{*}{ Direct investment } & 2.5 & 6.7 & 6.3 & 5.6 & 4.9 \\
\hline & \multicolumn{5}{|c|}{ (Annual percentage change, unless otherwise indicated) } \\
\hline Export volumes & 3.9 & 2.1 & 7.2 & -0.5 & 4.5 \\
\hline Import volumes & 15.0 & 26.6 & 4.1 & 3.9 & 3.1 \\
\hline Terms of trade & 7.9 & -5.7 & -3.6 & -3.1 & -0.5 \\
\hline End-of-year reserves (US\$ millions) ${ }^{2}$ & 9,907 & 11,414 & 12,898 & 13,968 & 15,061 \\
\hline (Months of imports of goods and services) ${ }^{3}$ & 24.4 & 26.9 & 28.6 & 29.4 & 29.5 \\
\hline
\end{tabular}

${ }^{1}$ Based on pula-denominated estimates converted at period-average exchange rate.

2 Includes valuation adjustment.

${ }^{3}$ Based on imports of goods and services for the following year. 
Table 11. Competitiveness Rankings*

\begin{tabular}{|c|c|c|c|c|c|c|}
\hline & 2001 & 2002 & 2003 & 2004 & 2005 & 2006 \\
\hline \multicolumn{7}{|c|}{ Business Competitive Index (BCl) Ranking } \\
\hline Argentina & 52 & 65 & 68 & 72 & 61 & 78 \\
\hline Botswana & & 53 & 55 & 57 & 55 & 69 \\
\hline Chile & 29 & 29 & 30 & 29 & 29 & 29 \\
\hline Colombia & 59 & 56 & 58 & 62 & 60 & 59 \\
\hline Lesotho & & & & & & 115 \\
\hline Malaysia & 37 & 25 & 24 & 23 & 23 & 20 \\
\hline Mauritius & 46 & 49 & 45 & 51 & 50 & 48 \\
\hline Namibia & $\ldots$ & 50 & 53 & 49 & 80 & 75 \\
\hline South Africa & 28 & 30 & 28 & 28 & 30 & 33 \\
\hline Swaziland & $\ldots$ & $\ldots$ & $\ldots$ & $\ldots$ & $\ldots$ & $\ldots$ \\
\hline No. of Countries & 74 & 79 & 97 & 100 & 113 & 121 \\
\hline \multicolumn{7}{|c|}{ Global Competitiveness Index Ranking } \\
\hline Argentina & $\ldots$ & $\ldots$ & $\ldots$ & $\ldots$ & 54 & 69 \\
\hline Botswana & $\ldots$ & $\ldots$ & $\ldots$ & $\ldots$ & 72 & 81 \\
\hline Chile & $\ldots$ & $\ldots$ & $\ldots$ & $\ldots$ & 27 & 27 \\
\hline Colombia & $\ldots$ & $\ldots$ & $\ldots$ & $\ldots$ & 58 & 65 \\
\hline Lesotho & $\ldots$ & $\ldots$ & $\ldots$ & $\ldots$ & $\ldots$ & 112 \\
\hline Malaysia & $\ldots$ & $\ldots$ & $\ldots$ & $\ldots$ & 25 & 26 \\
\hline Mauritius & $\ldots$ & $\ldots$ & $\ldots$ & $\ldots$ & 55 & 55 \\
\hline Namibia & $\ldots$ & $\ldots$ & $\ldots$ & $\ldots$ & 79 & 84 \\
\hline South Africa & $\ldots$ & $\ldots$ & $\ldots$ & $\ldots$ & 40 & 45 \\
\hline Swaziland & $\ldots$ & $\ldots$ & $\ldots$ & $\ldots$ & $\ldots$ & $\ldots$ \\
\hline No. of Countries & $\ldots$ & $\ldots$ & $\ldots$ & $\ldots$ & 117 & 125 \\
\hline \multicolumn{7}{|c|}{ Ease of Doing Business Ranking } \\
\hline Argentina & $\ldots$ & $\ldots$ & $\ldots$ & $\ldots$ & 93 & 101 \\
\hline Botswana & $\ldots$ & $\ldots$ & $\ldots$ & $\ldots$ & 44 & 48 \\
\hline Chile & $\ldots$ & $\ldots$ & $\ldots$ & $\ldots$ & 24 & 28 \\
\hline Colombia & $\ldots$ & $\ldots$ & $\ldots$ & $\ldots$ & 76 & 79 \\
\hline Lesotho & $\ldots$ & $\ldots$ & $\ldots$ & $\ldots$ & 116 & 114 \\
\hline Malaysia & $\ldots$ & $\ldots$ & $\ldots$ & $\ldots$ & 25 & 25 \\
\hline Mauritius & $\ldots$ & $\ldots$ & $\ldots$ & $\ldots$ & 32 & 32 \\
\hline Namibia & $\ldots$ & $\ldots$ & $\ldots$ & $\ldots$ & 39 & 42 \\
\hline South Africa & $\ldots$ & $\ldots$ & $\ldots$ & $\ldots$ & 28 & 29 \\
\hline Swaziland & $\ldots$ & $\ldots$ & $\ldots$ & $\ldots$ & 67 & 76 \\
\hline No. of Countries & $\ldots$ & $\ldots$ & $\ldots$ & $\ldots$ & 175 & 175 \\
\hline
\end{tabular}

* $1=$ most competitive

Sources: World Economic Forum , World Bank Doing Business 


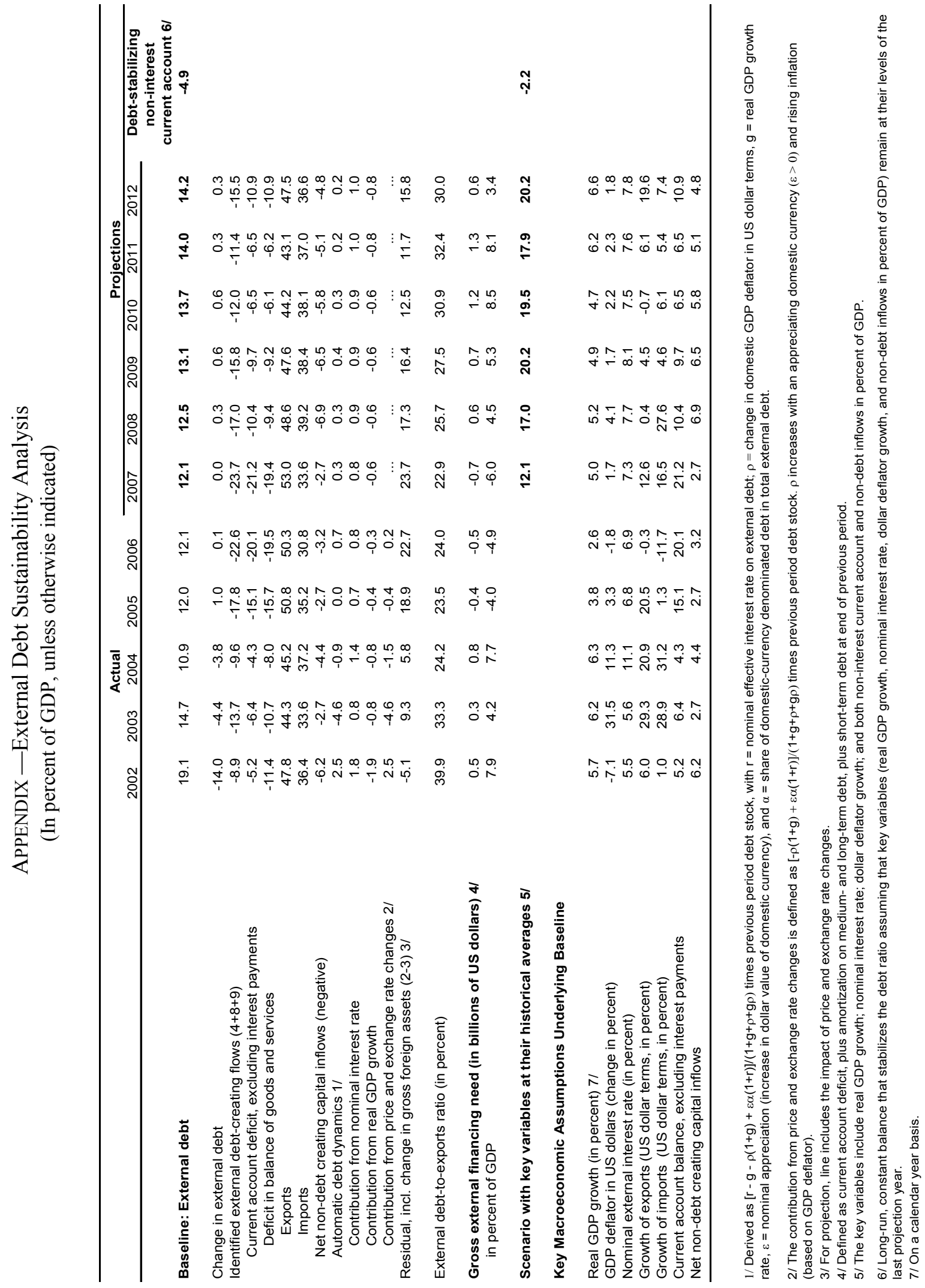


Figure 1. Botswana: External Debt Sustainability: Bound Tests 1/ (External debt in percent of GDP)
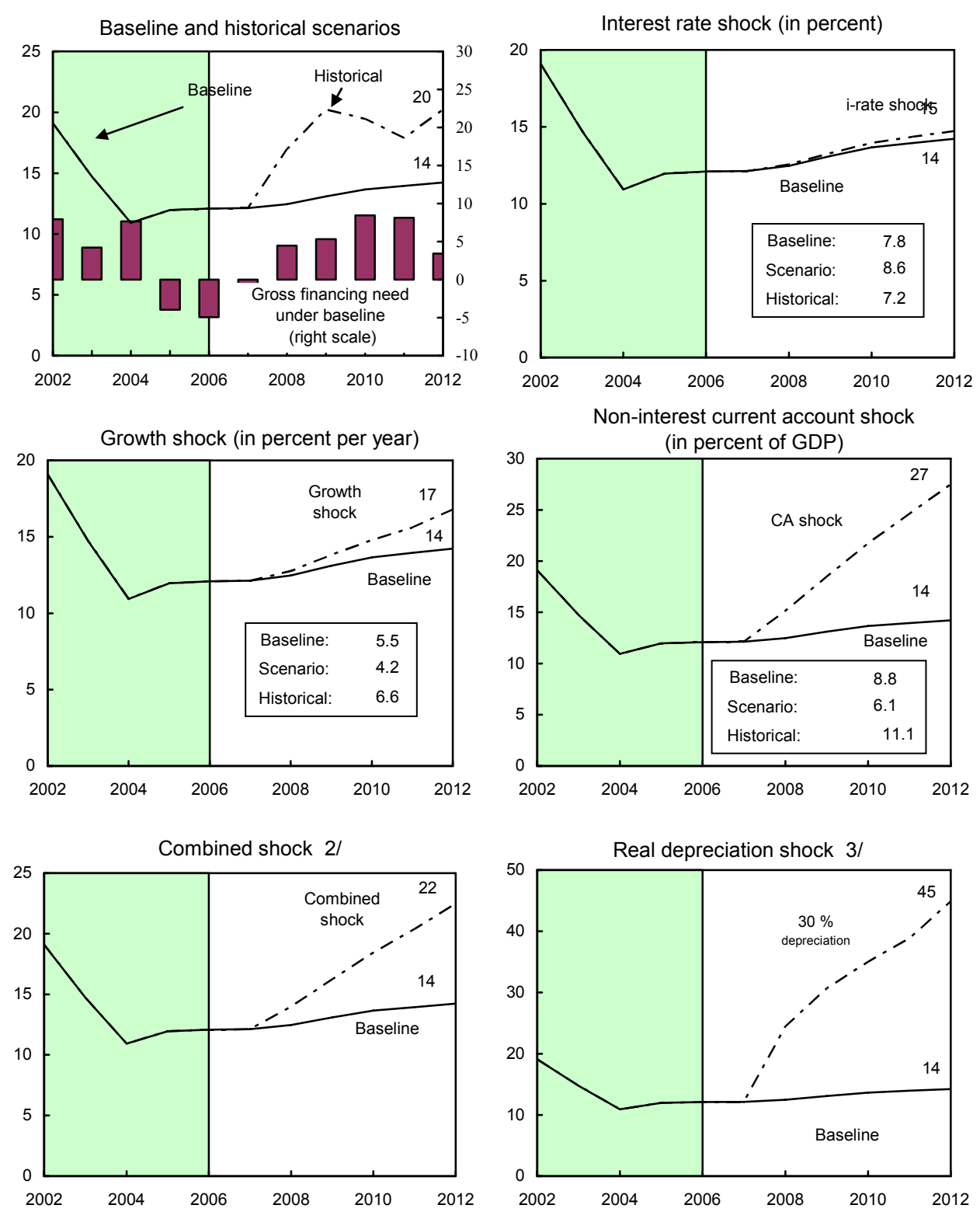

Sources: International Monetary Fund, Country desk data, and staff estimates.

1/ Shaded areas represent actual data. Individual shocks are permanent one-half standard deviation shocks. Figures in the boxes represent average projections for the respective variables in the baseline and scenario being presented. Ten-year historical average for the variable is also shown.

2/ Permanent 1/4 standard deviation shocks applied to real interest rate, growth rate, and current account balance.

3/ One-time real depreciation of 30 percent occurs in 2008. 


\section{INTERNATIONAL MONETARY FUND}

BOTSWANA

\section{Staff Report for the 2007 Article IV Consultation-Informational Annex}

Prepared by the African Department

(In consultation with other departments)

Approved by David Andrews and Anthony Boote

November 9, 2007

- $\quad$ Relations with the Fund: The last Article IV consultation was concluded in December 2006.

- $\quad$ Relations with the World Bank: Currently, Botswana, an IBRD country, has no lending program with the World Bank.

- Statistical Issues: Botswana subscribes to the General Data Dissemination System (GDDS). 


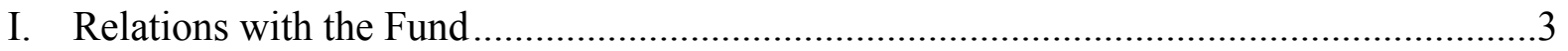

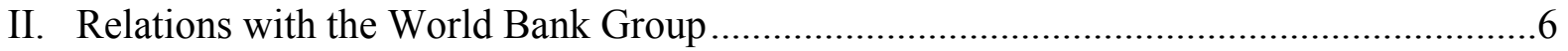

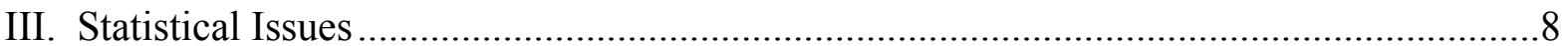




\section{Relations with the Fund}

(As of September 30, 2007)

I. Membership Status Joined July 24, 1968; Accepted the obligations of Article VIII, Sections 2, 3, and 4: November 17, 1995.
II. General Resources Account
Quota
$\underline{\mathrm{SDR} \text { (million) }}$
63.00
58.59
4.43
Fund holdings of currency
Percent of Quota
100.00
93.00
Reserve position in Fund
7.03
III. SDR Department

SDR (million)
4.36
38.07

Percent of Quota
100.00
873.30

IV. Outstanding purchases and loans

None

V. Financial arrangements

None

VI. Project obligations to Fund

None

VII. Implementation of HIPC Initiative

None

\section{Exchange rate arrangements}

The exchange rate of the Botswana pula is a crawling peg arrangement against a basket of currencies. As of September 30, 2007, the exchange rate of the U.S. dollar to the pula was $\mathrm{US} \$ 1=\mathrm{P} 6.06$, and that of the South African rand to the pula was R1=P0.88.

Directors noted in the context of the 2006 consultation that Botswana maintains a multiple currency practice (MCP) relating to exchange rate guarantees on one loan and urged the authorities to take early action to remove that practice. This MCP was eliminated, on August 8, 2007, with the conversion of the outstanding loan under the Foreign Exchange Risk Sharing scheme to a pula loan. 


\section{Article IV Consultation}

Botswana is on a standard 12-month consultation cycle. The last Article IV consultation was concluded by the Executive Board on December 13, 2006. Directors agreed with the thrust of the staff appraisal.

\section{Technical assistance assignments/projects}

Department

MFD

STA

1997

1999-2000

1997

\section{Position}

Central banking advisor Banking supervision advisor Balance of payments advisor

\section{Technical assistance missions}

Depa
MFD

FAD

LEG

STA

\section{Dates}

January 2001

February 2001

December 2001

August 2002

July 2004

August 2004

November 1997

September 2000

February 2002

November 2004

January 2006

July 2006

June 2007

May 2001

April 2002

July 2002

August 2003

June 2004

August 2004

October 2004

\section{Purpose}

Banking supervision advisor

Monetary operations

MEFMI-Monetary operations

Banking supervision, anti-money laundering

NBFI supervision

Money and banking statistics follow-up

Introduction of a VAT

Implementation of VAT next steps

Tax administration (SADC Region)

Public expenditure management

Review of amended VAT provisions

Review of central bank law

Review of VAT laws

Inspection for visit of long-term

balance of payments advisor

ROSC data module

BOP statistics: peripatetic visit

Monetary and financial statistics using the GDDS

GDDS project for Anglophone Africa:

National accounts statistics

Follow-up mission: Money and banking statistics

GDDS: National accounts mission 
June 2005

August 2005

March 2006

March 2006

October 2006

MCM

January, March

2007
Follow-up on monetary and financial statistics using the GDDS

Follow-up mission: GDDS quarterly balance of payments statistics GDDS project for Anglophone Africa:

balance of payments statistics

GDDS project for Anglophone Africa: national accounts statistics ROSC data module covering GDDS and Data Quality Assessment Framework (DQAF) IMF-World Bank Financial Sector Assessment Program (FSAP) 


\section{Relations with the World Bank Group}

(As of October 29, 2007)

1. Botswana became a member of the International Bank for Reconstruction and Development (IBRD) and the International Development Association (IDA) in 1968. Cumulative commitments from IDA to Botswana include US\$17 million for six development credits for infrastructural development and the livestock sector. The last credit was extended in 1974. Cumulative commitments from the IBRD to Botswana amount to US\$281 million for 22 loans, of which US\$54 million was canceled. The loans were extended for infrastructure development, the financial sector, land management, livestock development, and education and health projects. The last loan was extended in 1987. Since the late 1980s, the Government has not required external borrowing owing to its strong financial and international reserve position based on diamond mining receipts. As lending phased out, the Bank's involvement in Botswana shifted to limited analytical and advisory services.

2. Over the past decades, Botswana has demonstrated its capacity to address its development challenges effectively. However, the increasing sophistication of its development agenda makes it more critical than ever before to introduce international development experiences. The Government has therefore expressed interest in a closer partnership to benefit from the World Bank's comparative advantage in key development areas. Specifically, it has requested IBRD loans for two projects: one on HIV/AIDS and one on integrated transport. The HIV/AIDS project (about US\$56 million) is scheduled for delivery in the fourth quarter of fiscal year 2008 and the Transport project (about US $\$ 110$ million) in the first quarter of fiscal year 2009. Given that its upper middle-income status excludes Botswana from the World Bank's highly concessional IDA resources, the Government requested that the proposed HIV/AIDS operation be financed utilizing a relatively new instrument referred to as an IBRD "buy-down" which involves utilizing donor resources to lower the cost of an IBRD loan. The release of these donor funds would be dependent on project performance, with jointly agreed indicators and targets. The European Commission (EC) has indicated its strong interest in supporting the buy-down. Although final amounts still have to be confirmed, the EC has suggested that new funds of approximately US $\$ 20.6$ million would be available to support this effort. Given the expected EC contribution and Government's indicated preference for a 0 percent interest rate, a project size of approximately US\$56 million is proposed over a five-year period. In addition to the two IBRD operations under preparation, the Government has requested Bank support in the energy sector. The Bank is initiating discussions with the Government on an IBRD Partial Risk Guarantee (PRG) and possibly an IBRD loan. The Bank is also preparing a US\$5 million GEF grant-financed project on wildlife management and biodiversity conservation. A first-ever Interim Strategy for Botswana (24 months, Board in March 2008) will provide the strategic underpinning for the new lending operations and the growing partnership.

3. Recent Bank analytical work in Botswana includes an Export Diversification Report in FY05, ROSC on Accounting and Auditing, Livestock Sector Development Strategy, and Poverty and Social Impact Analysis in fiscal year 2006. The Bank conducted an Investment 
Climate Assessment in fiscal year 2007; some follow-up work is planned for fiscal year 2008. Through trust funds the Bank is supporting Botswana in statistical capacity building and monitoring and evaluation. Carbon Finance Assist, the World Bank's climate change capacity building program administered by the World Bank Institute, is launching technical assistance.

4. Botswana joined the International Finance Corporation (IFC) in 1979, but there has been little private sector interest in Botswana in IFC financing because high liquidity has enabled the private sector to raise funds in the domestic market. Cumulative IFC equity and loan commitments to Botswana total US\$10.72 million in five tourism, financial, and mining enterprises. In fiscal years 1999 and 2000, the IFC made two loan commitments amounting to US\$1.75 million to Abercombie and Kent (Botswana) for accommodation and tourism services projects in the Okavango Delta. In fiscal year 2001, the IFC made a quasi-equity investment of US\$3 million in the African Banking Corporation aimed at diversifying its range of financial services and increasing its geographical coverage. In fiscal year 2003, it approved a US\$2 million equity investment in Kalahari Diamonds Limited for exploration in the Kalahari desert. At the end of 2004, the IFC took an equity stake of US\$3.97 million in Letshego, a consumer finance company that provides short- to medium-term micro loans to public and private sector employees. IFC is currently negotiating a US\$20 million investment in African Banking Corporation to further support its regional expansion. It has also signed a mandate to provide Letshego with additional funding through a US\$20 million local currency loan that will also support Letshego's regional expansion plans.

5. The IFC has advised the Government of Botswana on privatization and in fiscal year 2004 the Public Enterprises Evaluation and Privatization Agency gave the IFC the privatization mandate for Air Botswana. IFC Advisory Services has been selected as Transaction Advisor for the structuring of a public-private partnership for the proposed Botswana International University of Science and Technology. The Corporation is also at the early stage of engaging on the privatization of Botswana Telecommunications Corporation.

6. In 2004, the Foreign Investment Advisory Service completed a review of the commercial law, administrative and registration costs, and barriers to investment in Botswana.

7. Botswana joined the Multilateral Investment Guarantee Agency (MIGA) in 1988; MIGA has no exposure and no active applications in Botswana.

World Bank Contacts: Mr. Dirk Reinermann, Lead Operations Officer, at 27-12-431-3144 Ms. Anna van der Wouden, Country Officer, at 2024582976 


\section{Statistical Issues}

1. Data provision is adequate to conduct surveillance, but there are some shortcomings. The accuracy of data, particularly for the national accounts and balance of payments, needs improvement. In addition, the current arrangements according to which balance of payments statistics are compiled on a calendar-year basis, the national accounts on a July-June schedule, and the budget on an April-March schedule, hamper the accuracy and integration of economic data and the analysis of savings-investment balances.

2. A ROSC reassessment took place October 31-November 13, 2006 and the report, along with the authorities' response, was published on April 6, 2007. Cross-cutting recommendations were to monitor the consistency of the main macroeconomic datasets and reconcile differences regularly; establish a list of institutional units consistent with sectorization in the 1993 System of National Accounts (1993 SNA), to be applied consistently across all datasets; and support greater use of preliminary data by formalizing revision policies and implementing regular revision cycles.

3. As one of 22 countries participating in the Fund's General Data Dissemination System (GDDS) Project for Anglophone African Countries, Botswana has undertaken to use the GDDS as framework for the development of its national statistical system. Botswana is participating in the monetary and financial statistics modules of the Anglophone Africa project (funded by the U.K. Department for International Development (DFID)). This project aims to assist participating countries to implement plans for improvement identified in the metadata, which were posted on the Fund's Dissemination Standards Bulletin Board on October 24, 2002.

\section{National Accounts and Prices}

4. Using the production and expenditure approaches, national accounts are now principally based on the concepts and definitions recommended by the 1993 SNA, in line with the strong commitment of the authorities to migrate to the $1993 \mathrm{SNA}$, but some changes are needed for full observance. For instance, classification and sector breakdowns are still broadly in line with 1968 SNA. Differences in the accounting periods and in the timing of recording between national accounts, balance of payments, and government finance statistics are still hindering the accuracy of estimates. Staff have encouraged the authorities to expedite the planned move to harmonize the accounting periods over the medium term. It would be important to conduct comprehensive enterprise surveys every few years and introduce estimates for the informal sector. Detailed recommendations are contained in the April 2007 ROSC report.

5. The consumer price index is comprehensive and provides breakdowns between urban and rural areas and between tradable (domestic and imported) and nontradables. The Classification of Individual Consumption by Purpose (COICOP) in the rebased CPI (September 2006) broadly conforms with the guidelines of 1993 SNA and the CPI Manual, although there are still deviations with respect to the imputation of rents and owner-occupied housing. Estimates from the Household Income and Expenditure Survey (HIES) are used for 
the weights of market expenditure for goods and services. With respect to the wholesale price index (WPI), the ROSC mission recommended the development of concepts and definitions to meet the needs of data users. The Central Statistics Office is to decide whether to produce an output index (PPI), an Intermediate Consumption Index or a Supply Price Index. Currently, the WPI of industrial output is not representative of industrial production, because it measures changes in the prices of only six product groups.

\section{Fiscal accounts}

6. The concepts and definitions used in compiling central government finance statistics generally follow the methodology of the IMF's Government Finance Statistics Manual (GFSM 1986) but cover only budgetary central government activities.. No fiscal statistics are compiled for extrabudgetary institutions and consolidated central government. The classification used for budgetary central government partially follows the concepts of GFSM 1986. Detail on some components of current spending is lacking. Transactions are recorded on a cash basis consistent with the GFSM 1986 guidelines. In general, the statistics disseminated in official publications are presented clearly and are made available to all users simultaneously. The data ROSC mission recommended at least annual compilation and dissemination of GFS for extrabudgetary institutions, and the consolidated general government. The authorities have yet to decide on a suitable "migration path" to adopt the GFSM 2001 methodology. The authorities regularly report monthly data on budgetary central government for inclusion in the International Financial Statistics, but no data are reported for inclusion in the Government Finance Statistics Yearbook.

7. The periodicity of central government finance statistics meets GDDS standards, except for timeliness. It should be noted that information is available to permit compilation and dissemination of government finance statistics within the GDDS recommendations.

\section{Monetary accounts}

8. The Bank of Botswana's (BoB) compilation of the depository corporations survey is generally consistent with the methodology recommended in the Fund's Monetary and Financial Statistics Manual (MFSM). The survey covers BoB and all other depository corporations that issue liabilities included in the national definition of broad money as recommended in the MFSM. Classification and sectorization are largely consistent with $M F S M$, except for the classification of financial derivatives. In addition, some nonbudgetary central government units are classified as nonfinancial public corporations and accrued interest is not consistently presented together with the underlying instrument.

9. Monetary data for publication in International Financial Statistics are reported regularly using Standardized Report Forms. Although reporting is more timely, data concerning the central bank are still being reported to STA with a longer lag than those for the other depository corporations. 


\section{External sector statistics}

10. The concepts, structure and definitions of the balance of payments statistics follow the fifth edition of the Balance of Payments Statistics Manual (BPM5). Institutional classifications generally follow BPM5, although data sources raise minor issues, in particular, administrative sources using definitions and classifications that deviate from BPM5. Source data are adequate, but International Transaction Reporting System (ITRS) data, used mostly for services, have become unreliable, and alternative data sources are needed. Data compilation, estimation, and adjustments mostly employ sound techniques. However, the methods for estimating missing data and calculating flows from stock data are inadequate.

11. Balance of payments statistics are compiled and published in the BoB's monthly statistical bulletin and the Annual Report, thus meeting GDDS periodicity and timeliness recommendations, although only annual balance of payments statistics are reported to STA for publication. There are discrepancies with national accounts statistics concerning imports, exports, and payments related to settlements within the Southern African Customs Union (SACU), mainly due to different data sources and valuation methods. 


\section{Botswana: Table of Common Indicators Required for Surveillance (As of October 23, 2007)}

\begin{tabular}{|c|c|c|c|c|c|c|c|}
\hline & & Date & & & Frequency & Mem & o items: \\
\hline & $\begin{array}{c}\text { latest } \\
\text { observation }\end{array}$ & received & of data $^{1}$ & $\begin{array}{l}\text { of } \\
\text { reporting }\end{array}$ & $\begin{array}{c}\text { of } \\
\text { publication }\end{array}$ & $\begin{array}{l}\text { Data quality - } \\
\text { methodological } \\
\text { soundness } \\
\end{array}$ & $\begin{array}{l}\text { Data quality - } \\
\text { accuracy and } \\
\text { reliability }^{3} \\
\end{array}$ \\
\hline Exchange rates & Sept. 2007 & $10 / 12 / 2007$ & M & M & M & & \\
\hline $\begin{array}{l}\text { International reserve assets and } \\
\text { reserve liabilities of the monetary } \\
\text { authorities } 4\end{array}$ & May 2007 & $8 / 10 / 2007$ & M & M & M & & \\
\hline Reserve/base money & July 2007 & $10 / 19 / 2007$ & M & M & M & $\mathrm{O}, \mathrm{O}, \mathrm{LO}, \mathrm{O}$ & LNO, O, LO, LO, LO \\
\hline Broad money & July 2007 & $10 / 19 / 2007$ & M & M & M & & \\
\hline Central bank balance sheet & July 2007 & $10 / 19 / 2007$ & M & M & M & & \\
\hline $\begin{array}{l}\text { Consolidated balance sheet of the } \\
\text { banking system }\end{array}$ & July 2007 & $10 / 19 / 2007$ & M & & M & & \\
\hline Interest rates ${ }^{5}$ & Aug. 2007 & $10 / 19 / 2007$ & M & M & M & & \\
\hline Consumer price index & Aug. 2007 & Oct. 2007 & M & M & M & $\mathrm{O}, \mathrm{LO}, \mathrm{O}, \mathrm{O}$ & LO, LO, LO, LO, O \\
\hline $\begin{array}{l}\text { Revenue, expenditure, balance and } \\
\text { composition of financing }{ }^{6} \text { - general } \\
\text { government }\end{array}$ & NA & NA & & & & LO, LNO, LNO, LO & LO, O, LO, LO, LNO \\
\hline $\begin{array}{l}\text { Revenue, expenditure, balance and } \\
\text { composition of financing } 6 \text { - central } \\
\text { government }\end{array}$ & Aug. 2007 & Oct. 2007 & $A / Q$ & Q & Q & & \\
\hline $\begin{array}{l}\text { Stocks of central government and } \\
\text { central government-guaranteed debt }\end{array}$ & NA & NA & & & & & \\
\hline External current account balance & 2006 & Oct. 2007 & A & $A$ & A & $\mathrm{O}, \mathrm{O}, \mathrm{O}, \mathrm{LO}$ & LO, LO, LNO, O, LO \\
\hline $\begin{array}{l}\text { Exports and imports of goods and } \\
\text { services }\end{array}$ & 2005 Q4 & April 2006 & $M / Q$ & M & Q & & \\
\hline GDP/GNP & 2006 & May 2007 & $A / Q$ & $\mathrm{~A} / \mathrm{M}$ & $\mathrm{A} / \mathrm{M}$ & LO, LO, LNO, LO & LO, LO, LNO, LO, LO \\
\hline Gross external debt & Mar. 2003 & Mar. 2003 & $\mathrm{~A} / \mathrm{Q}$ & $A$ & A & & \\
\hline
\end{tabular}

${ }^{1}$ Daily (D), weekly (W), monthly (M), quarterly (Q), annually (A), irregular (I), and not available (NA).

${ }^{2}$ Reflects the assessment provided in the data ROSC published on April 6,2007 and based on the findings of the mission that took place during October 31-November 13, 2006, for the data set corresponding to the variable in each row. The assessment indicates whether international standards concerning (respectively) concepts and definitions, scope, classification/sectorization, and basis for recording are fully observed (O), largely observed (LO), largely not observed (LNO), not observed (NO), or not available (NA).

${ }^{3}$ Same as footnote 2, except referring to international standards concerning (respectively) source data, assessment of source data, statistical techniques, assessment and validation of intermediate data and statistical outputs, and revision studies.

${ }^{4}$ Includes reserve assets pledged or otherwise encumbered as well as net derivative positions.

${ }^{5}$ Both market-based and officially determined, including discount, money market, treasury bill, note, and bond rates.

${ }^{6}$ Foreign, domestic bank, and domestic nonbank financing.

${ }^{7}$ The general government consists of the central government (budgetary funds, extra-budgetary funds, and social security funds) and state and local governments.

${ }^{8}$ Including currency and maturity composition. 


\section{Statement by Peter Gakunu, Executive Director for Botswana and Ita Mary Mannathoko, Advisor to Executive Director December 7, 2007}

\section{Introduction}

The Botswana authorities appreciate the constructive analysis and useful dialogue with staff during this year's Article IV consultation, as well as the well-researched inputs they provided during the Bank of Botswana (BOB) seminar. They thank staff for the well written, constructive and balanced report and selected issues paper, as well as for the FSAP assessment. They also thank the Deputy Managing Director Mr. Kato, for his participation in the concluding meetings of the mission and for his generous comments during his visit.

\section{Background}

Effective resource management, good governance and prudent macroeconomic policies have contributed to Botswana's sustained growth performance. Standard and Poors, and Moodys rating agencies have consistently given the country strong ratings. In August 2007, Moody's Investors Service retained Botswana's sovereign credit ratings of A2, Prime-1 and A1, for government debt, long term foreign currency debt, and short term foreign currency debt, respectively. It also upgraded the foreign currency outlook from "stable" to "positive". The World Economic Forum ratings for global competitiveness, quality of public institutions, and sustainable development; the World Bank's governance indicators for measures such as human rights and accountability, political stability, public service delivery, regulatory quality, rule of law and control of corruption; and the Global Economic Freedom Network, Freedom House, Carnegie Endowment, and Heritage Foundation ratings for economic freedom and openness, have consistently placed Botswana among the top in Africa. Notwithstanding these ratings, the authorities are conscious of the fact that in many areas, the economy lags behind comparator nations. The expectation of taxpayers is that the government should enable a quality of life at a level commensurate with its classification as an upper middle income country.

\section{Recent Economic Developments and Outlook}

The Botswana economy remains robust. Over the past year, macroeconomic stability has been preserved as reflected in the drop in inflation from a high of 14.2 percent in April 2006 to 7.3 percent in October 2007. However, as world prices for petroleum continue to rise and food shortages caused by drought and new bio-fuel demand emerge, inflationary pressures will remain. For the external sector, greater real exchange rate stability has now been attained at a level closer to the long run equilibrium. The past year has also seen a continued strengthening of the country's financial position with growing reserves in the wake of balance of payments and fiscal surpluses. The 2006 current account surplus was over 19 percent of GDP. Meanwhile in 2007/08 another fiscal surplus is likely, given projected 
SACU revenues and recent gains from improved tax collection. In the real sector, the high growth rate of 9.2 percent in the year ending June 2005 was followed by a temporary decline in growth reflecting the dominant influence of cyclical fluctuations in diamond output on overall GDP growth. Growth is now estimated to have picked up again in 2006/07 to 5.8 percent, with renewed business expansion as new investments come on stream in the mining, electricity, manufacturing and tourism sectors. Prospects for economic diversification away from diamond mining have improved.

In recent years, progress in human welfare has also been evident in the sharp reduction in unemployment and poverty levels, as well as in HIV/AIDS infection rates. Over the decade ending 2005/06, an annual average employment growth rate of 4.7 percent was achieved, enabling the unemployment rate to drop from 21.5 percent to 17.6 percent. Poverty levels declined from 47 percent in 1994 to 30 percent in 2004, while Botswana's HIV infection levels at 17.1 percent of the population overall are now lower than those recorded in neighboring states for the 15 to 49 age cohort. Nevertheless, while these indicators show improvement, the rates remain high. Consequently the authorities are committed to implementing policies and projects designed to increase productive employment and help avert the adverse social effects that would arise from a large young population without productive occupation.

\section{Performance on the Sustainable Growth and Economic Diversification Program}

Botswana's twenty-year strategy, Vision 2016 has the development of a "prosperous, productive and innovative nation" as one of its pillars. The Vision targets a diversified economy in which agriculture, industry, mining and services are all productive and vital components of economic activity, development is sustainable, and diversification is structured to substantially raise broad-based incomes. These priorities will require timely implementation of scheduled reforms, to allow for continued diversification within the mining sector and the rapid expansion of the private sector. Thus, while macroeconomic stability continues to be preserved, the acceleration of remaining reforms and the implementation of productive development projects is needed to place the non-mining economy on a higher growth trajectory, reduce unemployment especially among the youth, and raise welfare and household income levels to the Vision's targeted level, within a decade.

The economic pillar of Vision 2016 is being implemented through consecutive national development plans. In recent plans, the authorities have embarked on a program of sustainable growth and economic diversification. Under the current plan NDP 9, various structural reforms targeted at supporting private sector-led investment and growth are being implemented. As a result of ongoing efforts, there are now major new mineral-linked projects underway in Botswana, including the Diamond Trading Company (Botswana) and associated down-stream manufacturing activities. Other mineral and energy sector projects include the coal-based Mmamabula Export Power Station which was fast tracked this year with all agreements concluded and implementation scheduled to start within the year. Preparatory work for the expansion of the existing Morupule Power Station is also ongoing, with 
construction expected to start at year-end. At the same time, a major new refinery is being built at the Tati Nickel Mine.

As with diamond polishing, it too will process raw material, to add value.

While the mineral sector supports growth, the authorities recognize the importance of infrastructure necessary for more rapid non-mining sector expansion, economic diversification and sustainable growth over the long term. In addition, to improve service delivery, the government has undertaken to construct four dams, speed-up implementation of the rural electrification and rural telecommunication programmes, and to connect all public facilities in villages where there is backbone telecommunication infrastructure. Care is being taken by the authorities to phase these construction activities to ensure cost-effective and timely completion. While large investments are being financed by both the private sector in the mineral sector and the public sector in infrastructure, many smaller investments are being made by the private sector, revealing renewed confidence in the Botswana economy.

\section{Addressing Implementation Constraints}

The authorities are well aware of the need to boost implementation capacity in line with the program for sustainable growth and diversification. In the past, implementation of projects had been delayed by the need to meet the requirements of Environmental Impact Assessments, slow land allocation, poor performance of some contractors and service providers, as well as slow project design and tendering procedures. Consequently, particular attention is being given to addressing the bottlenecks. With this in mind and in addition to ongoing capacity development in line Ministries, government is monitoring project implementation more closely, while also liberalizing project implementation procedures to enable its agencies to more readily augment government and local contracting capacity by employing rated international construction companies, along with skilled and experienced manpower to help in implementing projects.

\section{Fiscal Policy}

The authorities expect fiscal surpluses in the near term. Even so, the next national development plan (NDP 10) will need to give increased attention to the framework for nonmineral growth with the possibility of a reduction in the non-mineral primary deficit. The Mid-Term Review of NDP 9 reassessed the Fiscal Rule to ensure that it is consistent with what is required to achieve the country's vision and in particular the goal of sustainable economic diversification. Under the Fiscal Rule, expenditure has been smoothed out - set at a stable level over time that will allow for the achievement of current goals in the growth and diversification program. The authorities concur nevertheless, that more analysis should be done for NDP 10 to provide a more detailed analytic framework incorporating updated projections of future mineral receipts. Once mineral revenues or SACU receipts decline, the authorities agree that options to off-set these losses will have to be explored, and this may include another VAT increase. In the mean time, authorities are continuing to work at improving tax compliance and enhancing non-mineral revenue collection. At the same time, rationalization of public spending continues and in this respect, there may be opportunity to rationalize wage policies as part of the current review of public sector wages. 
On long term savings, the authorities felt that the Pula Fund had served them well so far. Nevertheless they agree to review current work being done on sovereign wealth funds and in this respect, one of the Deputy Governors of the Bank of Botswana participated in the recent IMF seminar on this subject.

\section{Monetary, Exchange Rate and Financial Sector Policies}

The real effective exchange rate has stabilized close to its equilibrium value in the past year as a result of fiscal restraint and tight monetary policy. Nevertheless, the authorities are cognizant of the importance of ensuring an appropriate balance between monetary and exchange rate objectives, in order to support competitiveness, and are looking more closely at this issue. In the monetary sector, the authorities acknowledge that systemic excess liquidity and the rising stock of Bank of Botswana certificates remain a challenge. They are committed to finding a solution to this issue, and government's rolling over of the Pula bond in 2008 is a step in this direction.

In the financial sector, the banking industry is financially sound, solvent, profitable and liquid, with banks maintaining prudential ratios in excess of current statutory requirements, and low ratios of non-performing loans. However, it remains shallow with indicators well below those of comparator countries. The authorities have also noted the rapidly changing financial landscape and are aware of the sizable financial sector regulation and development agenda necessitated by the rapid expansion in the non-bank financial sector. For this reason, they are beginning to put in place systems and a broad reform plan going forward. They appreciate the work done by the Fund and the Bank in the recent FSAP assessment and hope to continue to draw on the Fund's Technical Assistance where necessary now that an autonomous Financial Supervisory Authority has been set up to regulate and supervise nonbank financial institutions.

\section{Structural reforms}

Raising productivity remains a priority. To this end, the government is committed to reforms aimed at creating a conducive environment for business. After some initial delays, progress is now being made in implementing reforms recommended by the foreign investment advisory services (FIAS) report of the World Bank. Company registration procedures have been simplified resulting in a reduction in the time taken to register a company. The Industrial Development Act was amended to reduce the waiting period for licenses to one week. The Copyright and Neighbouring Rights Act was amended to better protect the copyright of artists against piracy and infringements. There have been legislative reforms and computerization in the area of land management and allocation. Market access for Botswana goods and services is being enhanced through bilateral and multilateral trade negotiations, while recognizing the challenge of competition this introduces for local producers, where reciprocity is required.

In addition to the on-going public service reforms, measures adopted to improve efficiency include the introduction of Public Private Partnership (PPP) approaches to projects, outsourcing of some public services to the private sector, and rationalization of some public 
enterprises to avoid duplication of roles. While the government remains committed to privatization and commercialization in line with the Privatization Policy Master Plan, it believes that the process should be done through proper consultation with concerned stakeholders, and in a transparent manner.

Other efforts to improve efficiency will require a review of administered prices to assess where it may be appropriate to introduce a market-linked adjustment mechanism. Some price increases are a one-off occurrence, such as the recently re-introduced school fees (for those above a stipulated income level) under the government's cost-sharing scheme. With respect to government data systems, consideration would continue to be given to the possibility of transforming the Central Statistics Office into a more efficient, autonomous agency.

\section{Conclusion}

Over the next few years, significant investments will come on stream in the infrastructure, education and mineral sectors. The infrastructure and higher education investments will help to release the potential for higher sustainable growth, and for diversification, in line with the goals of the ninth national development plan. Private sector investments in mining and manufacturing will also support these goals. The authorities realize, however, that the stimulus to growth that is expected may not be enough to make up fully for the slower than targeted growth during the first half of NDP 9. Notwithstanding the scaled up activity, the authorities remain committed to raising productivity, ensuring efficient investments, and maintaining macroeconomic stability.

In closing, we welcome the fact that the recent dialogue between the authorities and the staff has been fruitful. We wish to reiterate the authorities strong commitment to measures needed to address economic challenges ahead and trust that the Fund will continue to be responsive in providing the technical assistance requested by the authorities to strengthen their ability to put in place essential systems and implement necessary measures. 
Public Information Notice (PIN) No. 08/13

FOR IMMEDIATE RELEASE

February 8, 2008
International Monetary Fund

$70019^{\text {th }}$ Street, NW

Washington, D. C. 20431 USA

\section{IMF Executive Board Concludes 2007 Article IV Consultation with Botswana}

On December 7, 2007 the Executive Board of the International Monetary Fund (IMF) concluded the Article IV consultation with Botswana. ${ }^{1}$

\section{Background}

Sound macroeconomic policies, good governance, and high investment have moved Botswana well into the ranks of middle-income countries. Real GDP growth has averaged $4 \frac{1}{2}$ percent for the past four years, a solid performance, but below the expectations of the National Development Plan 9, which ends with fiscal year 2008/09 (April 2008-March 2009). Inflation has fallen close to the average for the South African rand area, and balance of payments and fiscal surpluses have built reserves and reduced Botswana's already low external debt.

Despite impressive progress in raising living standards, the incidence of poverty, unemployment, and HIVIAIDS are still high, although they have all declined recently. Botswana has made substantial progress but still has a considerable way to go to meet all the Millennium Development Goals by 2015.

\footnotetext{
${ }^{1}$ Under Article IV of the IMF's Articles of Agreement, the IMF holds bilateral discussions with members, usually every year. A staff team visits the country, collects economic and financial information, and discusses with officials the country's economic developments and policies. On return to headquarters, the staff prepares a report, which forms the basis for discussion by the Executive Board. At the conclusion of the discussion, the Managing Director, as Chairman of the Board, summarizes the views of Executive Directors, and this summary is transmitted to the country's authorities.
} 
After a temporary slowdown, growth recovered in $2006 / 07$ to an estimated $53 / 4$ percent, thanks to increased non-mineral as well as mineral activity, especially in tourism and manufacturing. Inflation has fallen substantially since peaking in April 2006 and has stabilized just around the upper limit of the authorities' inflation objective of 4-7 percent. In June, the Bank of Botswana $(\mathrm{BoB})$ lowered its policy interest rate half a percent, to $14 \frac{1}{2}$ percent. Money supply (M3) has grown steadily and private sector credit rose 19 percent in July 2007 year-on-year.

The fiscal surplus rose substantially in 2006/07 to 12 percent of GDP, as a result of higher revenues from minerals and the South African Customs Union (SACU) combined with slowed capital spending. Another large surplus is expected in 2007/08. Continued high mineral prices and a decline in imports contributed to a current account surplus of almost $19 \frac{1}{2} 2$ percent of GDP in 2006, and international reserves increased to 25 months of prospective imports of goods and services.

Exchange rates have stabilized in the past year. The pula depreciated significantly in nominal and real effective terms after devaluations in 2004 and 2005 and the shift in 2005 to a crawling peg. The rate of crawl of the pula is set at the difference between the inflation objective and the forecast inflation of Botswana's trading partners. Fiscal restraint, capital account outflows, and tight monetary policy have helped to contain inflationary pressures so that the real effective exchange rate (REER) is now about 10 percent below its peak before the 2004 devaluation.

Over the medium term, continued and prospective development of diamonds, copper, nickel, and coal; large-scale investment in electricity generation; and some promising nonmineral projects should support growth and maintain fiscal and balance of payments surpluses through 2011. But further enhancement of non-mineral growth is necessary to offset the expected sharp decline in diamond production sometime after 2020. Even in a growing economy, it will be difficult for the government to replace the high share of diamond export revenues it currently receives.

\section{Executive Board Assessment}

Directors commended Botswana's continued impressive record of sound macroeconomic policies and good governance, which has moved the country into the ranks of middleincome countries. Directors welcomed the recent increase in growth and reduction in inflation, as well as the continued strong balance of payments and fiscal surpluses. They urged the authorities to sustain their recent success at reducing the incidence of poverty, unemployment, and HIVIAIDS, and to continue to strive to meet all the Millennium Development Goals.

Directors observed that, despite this impressive record, Botswana faces the challenges of diversifying the sources of growth and reducing the economy's heavy dependence on diamond production. While a number of promising projects, such as in electricity generation, will contribute to a broadening of the economic base and to growth prospects 
in the medium term, Directors called for the next National Development Plan to incorporate structural reforms aimed at strengthening further the environment for non-mineral-based activities.

Directors agreed that securing a strong and stable fiscal position and high-quality capital spending will help support growth, as will a further strengthening of non-mineral revenues. They commended the authorities for attaining their principal fiscal goals of maintaining surpluses in the overall and non-investment balances, and limiting public expenditures to less than 40 percent of GDP. At the same time, many Directors advocated a spending ceiling of closer to 30 percent of GDP--still leaving room for the growth of HIVIAIDS-related and capital spending. Many also suggested considering an additional fiscal policy benchmark, based on permanent mineral income estimations, to set the non-mineral primary deficit at a sustainable level.

On the other hand, some Directors saw merit in maintaining the present fiscal strategy, which is working well and would better ensure that resources are available for infrastructure investments and human capital development. Directors welcomed the sound management of the Pula Fund, while recommending adjustments to its institutional framework to strengthen public savings and promote transparency. In this context, a few Directors referred to the possibility of establishing an explicit sovereign wealth fund independent of the central bank's balance sheet.

Turning to monetary and exchange rate policies, Directors observed that the last devaluation of the pula had provided a boost to exports, but real interest rates had remained high. They therefore supported the early summer 2007 reduction of the nominal interest rate and the slowing of the rate of crawl of the pula exchange rate. A further slowing of the rate of crawl would help reduce inflationary pressures. From a longer-term perspective, Directors noted the difficulties of striking an appropriate balance between the authorities' monetary and exchange rate policy objectives, with most Directors advising the authorities to focus on price stability going forward. Competitiveness concerns could best be addressed by advancing structural reforms and improving the business environment.

Directors endorsed the recent measures to reduce excess liquidity, including improving treasury cash management. They encouraged the authorities to sustain these efforts to ease the burden on the Bank of Botswana.

Directors welcomed the conclusions of the recent Financial Sector Assessment Program that the banking sector is sound and near-term risks are well contained. At the same time, they encouraged the authorities to formulate a comprehensive financial sector reform plan to address the remaining agenda for financial deepening. They looked forward to the full implementation of the nonbank financial institutions regulatory authority in January 2008, the completion of the pension and insurance reform legislation, and the strengthening of the Anti Monetary Laundering and Combating the Financing of Terrorism (AML/CFT) framework through the establishment of the Financial Intelligence Unit. 
Directors encouraged the authorities to lay the groundwork for further structural reforms going forward, in order to support non-mineral growth. They called for the privatization of large parastatals within an appropriate regulatory framework, and for further efforts to build human capital, develop the private sector, and enhance Botswana's attractiveness to foreign direct investment.

Directors noted that Botswana's economic statistics are generally adequate for surveillance. They supported the continued upgrading of Botswana's statistical capacity.

Public Information Notices (PINs) form part of the IMF's efforts to promote transparency of the IMF's views and analysis of economic developments and policies. With the consent of the country (or countries) concerned, PINs are issued after Executive Board discussions of Article IV consultations with member countries, of its surveillance of developments at the regional level, of post-program monitoring, and of ex post assessments of member countries with longer-term program engagements. PINs are also issued after Executive Board discussions of general policy matters, unless otherwise decided by the Executive Board in a particular case. The staff report (use the free Adobe Acrobat Reader to view this pdf file) for the 2007 Article IV Consultation with Botswana is also available. 


\section{Botswana: Selected Economic Indicators}

\begin{tabular}{|c|c|c|c|c|c|}
\hline & 2003 & 2004 & 2005 & $\begin{array}{l}2006 \\
\text { Prel. }\end{array}$ & $\begin{array}{l}2007 \\
\text { Proj. }\end{array}$ \\
\hline & \multicolumn{5}{|c|}{ (Annual percentage change) } \\
\hline \multicolumn{6}{|l|}{ Production, prices, and money } \\
\hline Real GDP & 3.1 & 9.2 & -0.8 & 5.8 & 4.3 \\
\hline Minerals & 0.3 & 18.1 & -4.4 & 5.7 & -4.3 \\
\hline Non-minerals & 5.0 & 3.3 & 1.8 & 5.8 & 10.4 \\
\hline Consumer prices (end of period) & 6.4 & 7.9 & 11.3 & 8.5 & 7.4 \\
\hline Broad money & 17.6 & 13.9 & 10.6 & 67.4 & 23.6 \\
\hline & \multicolumn{5}{|c|}{ (Percent of GDP, unless otherwise specified) } \\
\hline \multicolumn{6}{|l|}{ Government operations } \\
\hline Total revenue and grants & 38.8 & 37.5 & 40.3 & 42.5 & 41.1 \\
\hline Total expenditure and net lending & 39.0 & 36.3 & 31.9 & 30.7 & 33.1 \\
\hline Overall balance after grants (cash basis) & -0.2 & 1.2 & 8.4 & 11.8 & 8.0 \\
\hline $\begin{array}{l}\text { Non-mineral primary balance (cash basis, as a percent of non-mineral } \\
\text { GDP) }{ }^{1}\end{array}$ & -33.6 & -27.2 & -20.5 & -15.3 & -17.6 \\
\hline & \multicolumn{5}{|c|}{ (Percent of GDP, unless otherwise specified) } \\
\hline \multicolumn{6}{|l|}{ External sector } \\
\hline Balance of payments (including official transfers; deficit -) & 1.9 & -0.6 & 13.2 & 16.6 & 17.2 \\
\hline Current account balance (including official transfers; deficit -) & 5.6 & 2.9 & 14.4 & 19.3 & 20.4 \\
\hline Outstanding medium- and long-term public debt & 5.4 & 4.3 & 4.1 & 3.5 & 2.7 \\
\hline Real effective exchange rate (annual average percentage change) ${ }^{2}$ & 3.3 & -5.4 & -3.0 & -2.6 & \\
\hline Gross official reserves (in millions of U.S. dollars) & 5,339 & 5,653 & 6,278 & 7,954 & 9,907 \\
\hline Reserves (in months of prospective imports of goods and services) & 17.5 & 18.3 & 23.0 & 25.0 & 24.4 \\
\hline
\end{tabular}

Sources: Botswana authorities and staff estimates and projections.

${ }^{1}$ Excluding mineral revenues, and interest earned and paid.

${ }^{2}$ Negative values indicate depreciation. 